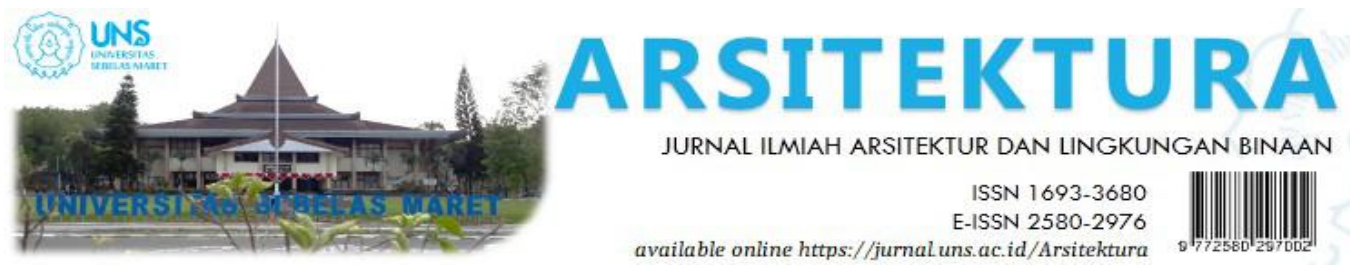

Volume 17 Issue 2 October 2019, pages: 231-248

\title{
Pengaruh Desain Penghawaan terhadap Kondisi Termal di Gereja Santo Petrus Sambiroto Semarang
}

\section{The Effect of Ventilation Design on Thermal Conditions in The Saint Peter Church Sambiroto Semarang}

\author{
Ardian Dewandaru ${ }^{1 *}$, Wahyu Setia Budi ${ }^{2}$, Gagoek Hardiman ${ }^{3}$ \\ Master Program of Architecture, Faculty of Engineering, Diponegoro University ${ }^{1^{*}}$ \\ Email : ardiandewandaru@students.undip.ac.id \\ Department of Physics, Faculty of Sciences and Mathematics, Diponegoro University ${ }^{2}$ \\ Department of Architecture, Faculty of Engineering, Diponegoro University ${ }^{3}$
}

DOI: https://doi.org/10.20961/arst.v17i2.30676

Received: July 7, 2019 Revised: October 17, 2019 Accepted: October 17, $2019 \quad$ Available online: October 31, 2019

\begin{abstract}
Saint Peter Church Sambiroto located in the Semarang City which has tropical climate. The building has many openings like doors and bouvenlights. Currently in the east corridor are given tents to accommodate the number of congregations that exist, and on the east side the hallway is paired with banner to protect the east hallway from sun's heat. The researcher will examine how openings play a role in creating thermal conditions in buildings. This research method uses field measurement techniques in the church regarding dry temperature, relative humidity and air movement in the church at each worship time in the morning and evening and at point where there are openings and not. After doing research, it was found that the temperature in the morning was still in a comfortable condition but at the evening temperature was above comfortable conditions. Even though all measuring points are affected by fan, the point where has opening has low temperature than where has no opening, in the point where has banner have higher temperature than no banner. This proves that openings play a role in flowing air into the building and banners blocking the air to entering lobby and building area from the east side.
\end{abstract}

Keywords: church; ventilation; wind obstacle; thermal condition

\section{PENDAHULUAN}

\subsection{Latar Belakang}

Terkait dengan penelitian ini, terdapat beberapa jurnal maupun buku yang terkait dengan penelitian ini, diantaranya adalah :

Menurut (Razak, 2015) yang meneliti mengenai karakteristik ventilasi dan lingkungan terhadap tingkat kenyamanan termal mengungkapkan bahwa sistem penghawaan bangunan sering disebut ventilasi, ventilasi bisa berupa ventilasi alami (tanpa alat/mesin), ventilasi buatan (dengan alat mesin yang menurunkan suhu dan kelembaban), dan ventilasi semi buatan (yaitu ventilasi yang dibantu dengan kipas angin dengan tujuan untuk membuat udara bergerak tapi tidak menurunkan suhu.

Menurut (Aflaki, Mahyuddin, Al-Cheikh Mahmoud, \& Baharum, 2015) di dalam penelitian yang dilakukan mengenai pengaplikasian ventilasi alami pada komponen fasad bangunan dan bukaan pada daerah tropis mengungkapkan bahwa dalam 
desain bangunan penghawaan alami memiliki beberapa keungungan yaitu 1) dengan penghawaan alami biaya yang dikeluarkan untuk system penghawaan dapat dikurangi, 2) dapat mengingkatkan kenyamanan termal dalam bangunan tersebut. 3) memberikan kualitas udara alami yang lebih baik.

Menurut (Frick Heinz, Ardiyanto Antonius, Darmawan AMS 2008) dalam buku Fisika Bangunan, jika penyegaran udara seara alami tidak dapat menimbulkan kenyamanan maka harus dibantu dengan penyegaran udara secara mekanis untuk meningkatkan laju pergerakan udara di dalam bangunan di tempat yang tidak tersaluri aliran udara dari luar. Contoh penghawaan mekanis yang paling sederhana adalah kipas angin.

Kenyamanan termal adalah kondisi pikiran yang dirasakan manusia yang mengungkapkan atau menunjukan kepuasan dirinya pada kondisi termal disekitarnya. (Koenigsberger, Ingersoll, Mayhew, \& Szokolay, 1974). Sedangkan menurut (Soegijanto, 1998) dan (SNI 03-6572-2001) tentang Cara Perancangan Sistem Ventilasi dan Pengkondisian Udara pada Bangunan Gedung menyatakan bahwa kenyamanan termal di daerah tropis menurut mom adalah sebagai berikut .

(1). $20.5^{\circ} \mathrm{C} \quad-22.8^{\circ} \mathrm{C} \quad$ masuk dalam kategori sejuk nyaman; (2). $22.8^{\circ} \mathrm{C}-25.8^{\circ} \mathrm{C}$ masuk dalam kategori nyaman optimal; (3). $25.8^{\circ} \mathrm{C}-27.1^{\circ} \mathrm{C}$ masuk dalam kategori hangat nyaman.

Pergerakan udara yang disarankan menurut (S.V Szokolay, 1980) adalah lebih dari $0.2 \mathrm{~m} / \mathrm{s}$. sedangkan kriteria kriterianya adalah :

(1). $0 \mathrm{~m} / \mathrm{s}-0.25 \mathrm{~m} / \mathrm{s}=$ tidak terasa; (2). 0.25 $\mathrm{m} / \mathrm{s}-0.50 \mathrm{~m} / \mathrm{s}=$ nyaman; (3). $0.50 \mathrm{~m} / \mathrm{s}-1.00$ $\mathrm{m} / \mathrm{s}=$ udara dapat dirasakan kulit; (4). 1.00 $\mathrm{m} / \mathrm{s}-1.50 \mathrm{~m} / \mathrm{s}=$ berangin; (5). Diatas 1,50 m/s $=$ berangin yang mengganggu.

Kelembaban udara menurut (S.V Szokolay, 1980) adalah $30 \%-65 \%$ (dengan toleransi sampai $77 \%$ ).

Dalam penelitian mengenai kenyamanan termail dalam ruangan di daerah tropis (Santoso, 2012). Menjelaskan bahwa untuk mencapai tingkat atau kondisi termal yang dinginkan maka dapat dilakukan tindakan yang dirasa diperlukan oleh penghuni yaitu dengan mengatur system ventilasi dan mengatur penghawaan secara mekanis, memberi tirai shading pada bagian yang terpapar panas matahari langsung untuk mengurangi panas matahari.

Penelitian terkait bangunan di daerah tropis kaitannya dengan bukaan dan penghalang angin telah dilakukan dan akan dijadikan sebagai pembanding dan acuan diantaranya adalah :

(Rusmiatmoko, Setyowati, \& Hardiman, 2018) telah meneliti pengaruh bukaan terhadap kondisi termal di Bangunan Sobokartti, dan mendapatkan hasil bahwa bukaan sangat berperan terhadap kondisi termal dalam bangunan. Di bangunan ini terdapat banner dan kisi kisi yang menjadi penghalang angin untuk masuk ke bangunan akan tetapi walaupun terhalang banner dan kisi kisi, presentase bukaan pada bangunan ini telah memenuhi standard yaitu lebih dari 5\% dari luas lantai.



Gambar 1. Banner dan Kisi Kisi pada Selasar Bangunan Sobokartti

Sumber: Rusmiatmoko et al., 2018.

Banner yang ditunjukkan pada Gambar 1, dengan warna merah dan kisi kisi yang ditunjukkan dengan warna putih yang ada pada area bukaan di bangunan sobokarti ini mirip dengan yang ada pada bangunan gereja yang menjadi objek penelitian yaitu sama sama terdapat wind obstacle yang menghalangi aliran udara. Rusmiatmoko telah meneliti bahwa luas bukaan yang ada telah sesuai dengan (SNI 03-6572-2001), sehingga suhu di dalam ruang sesuai dengan standard suhu efektif di daerah tropis menurut mom. Penelitian ini dijadikan sebagai pembanding karena memiliki kesamaan dengan objek penelitian penulis yaitu memiliki wind obstacle atau penghalang angin di area selasar, teras bangunan.

(Amin, Danusputra, \& Prianto, 2004). Melakukan penelitian dengan objek masjid 
yang dimana diperoleh hasil bahwa titik yang mempunyai suhu efektif rendah berada di dekat bukaan, daripada di titik yang berada tidak dekat dengan bukaan dan ventilasi silang. Penelitian ini dijadikan pembanding karena objek ini memiliki kesamaan yaitu memiliki bukaan yang banyak serta digunakan untuk kegiatan dengan jumlah manusia yang banyak. (Sekatia, Setyowati, \& Hardiman, 2015) melakukan penelitian terhadap ventilasi bawah pada gereja dan diperoleh hasil bahwa ventilasi bawah berpengaruh kepada suhu efektif gereja, seperti pada Gambar 2.

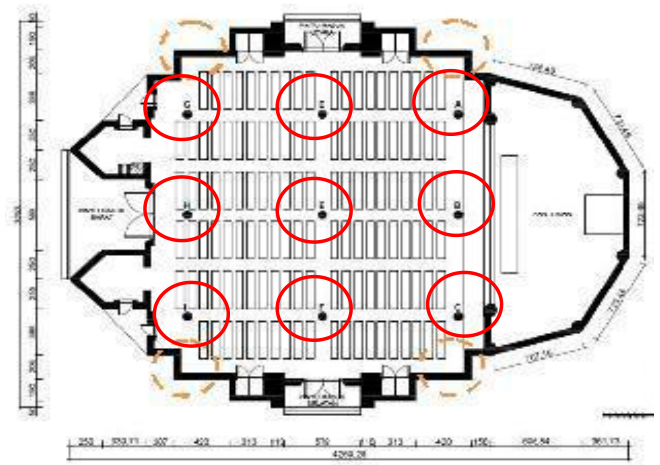

Gambar 2. Titik Ukur pada Gereja Katedral Sumber: Sekatia, Setyowati, \& Hardiman, 2015.

Penelitian ini dipilih sebagai pembanding karena objek penelitian memiliki kesamaan yaitu berupa gereja, sama sama meneliti tentang penghawaan dan penulis mengambil contoh titik ukur dari penelitian ini.

(Prianto, Bonneaud, Depecker, \& Peneau, 2000) melakukan penelitian mengenai ventilasi alami dalam dunia arsitektur di daerah tropis lembab dengan studi kasus rumah tradisional Indonesia.

Didapatkan hasil bahwa desain bangunan arsitektur yang ada di daerah tropis berkaitan erat dengan iklim. Kreativitas duni arsitektural yang didukung dengan ventilasi alami adalah permasalahan utama dari bangunan di daerah tropis lembab.

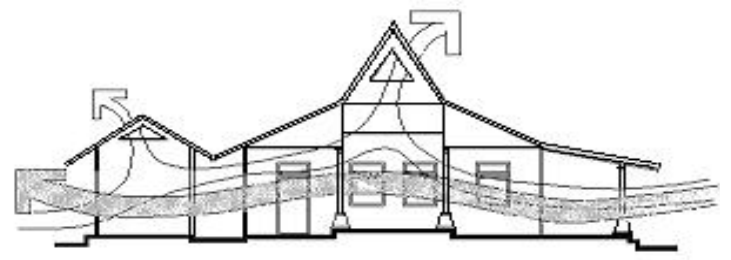

Gambar 3. Aliran Udara pada Bangunan di Daerah Tropis

Sumber: Prianto et al., 2000.
Gambar 3 merupakan alur pergerakan udara didaerah tropis, penelitian ini dipilih untuk menjadi pembanding karena penelitian ini meneliti kondisi termal dan pergerakan udara pada daerah tropis di bangunan tanpa wind obstacle.

(Carera \& Prianto, 2016) melakukan penelitian di gereja blenduk kota semarang mengenai kondisi termal di gereja blenduk, pengukuran dilakukan pada hari minggu pukul 9 sampai 11 dengan kondisi terdapat ibadah, standfloor AC sejumlah 4 buah dalam kondisi hidup, jendela tertutup, dan lubang ventilasi di bawah jendela dibiarkan terbuka. Dan dipdapatkan hasil bahwa zona kenyamanan berada di titik dekat bukaan. Penelitian ini dipilih karena memiliki objek yang sama yaitu gereja dan memiliki bukaan yang masih terbuka pada saat misa.

Menurut (SNI 03-6572-2001) tentang Tata Cara Perancangan Sistem Ventilasi dan Pengkondisian Udara pada Bangunan Gedung bukaan yang dianjurkan pada ruangan minimal adalah 5\% dari luas lantai.

Setelah menganalisa penelitian dan teori yang telah ada maka diambil keputusan bahwa penelitian ini meneliti bagaimana peran bukaan pada bangunan pada dinding gereja, posisi penghawaan mekanis berupa kipas angin dan kondisi bukaan pada selasar (dengan adanya wind obstacle) terhadap kondisi termal pada ruang ibadah jemaat di Gereja Santo Petrus Sambiroto.

Kepentingan dari penelitian ini adalah sebagai sebuah cara untuk mempelajari kondisi termal gereja kaitannya dengan kondisi bukaan yang ada saat ini mengingat gereja ini didesain dengan konsep tropis namun saat ini ada banner yang mengurangi luas bukaan dan memberikan saran bagaimana desain yang tepat pada sisi selasar jika kedepannya akan dibangun bangunan permanen.

Tujuan dari penelitian ini adalah untuk mengetahui kondisi termal gereja terkait kondisi yang ada saat ini guna memberikan solusi desain yang tepat untuk saat ini dan apabila sisi selasar akan dibangun. 


\section{METODE}

\subsection{Deskripsi Objek}

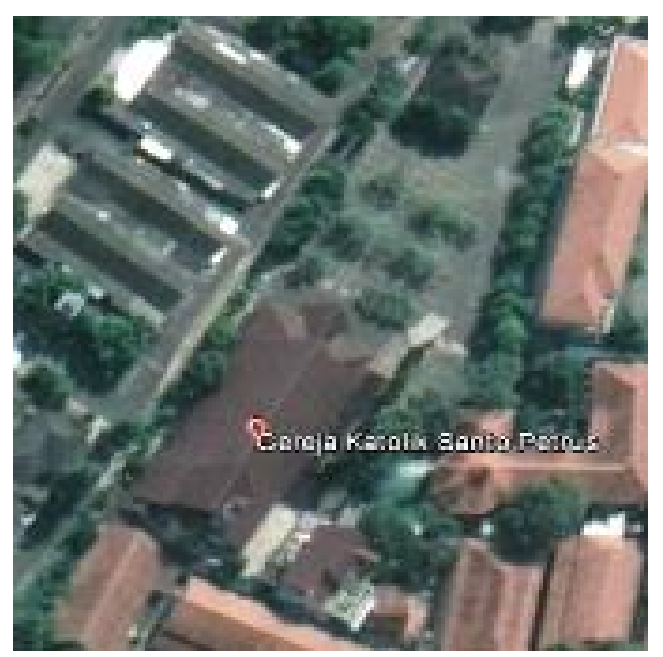

Gambar 4. Lokasi Gereja Santo Petrus Sambiroto Sumber: Google Earth - diakses pada 13 Juni 2019 pukul 09.00 WIB

Gereja Santo Petrus Sambiroto adalah sebuah gereja yang berada di jalan Arumsari Kelurahan Sambiroto kecamatan Tembalang Kota Semarang Jawa Tengah. Gambar 4 merupakan lokasi site gereja, pada gambar tersebut ditunjukkan bahwa posisi bangunan bereja berada di sisi selatan tapak.



Gambar 5. Fasad Gereja Santo Petrus Sambiroto

Gereja berukuran 1116 meter persegi ini dibangun dengan konsep tropis, hal ini bisa dilihat dari banyaknya bukaan yang terdapat di bangunan gereja, di gereja ini bukaan terdiri dari 2 hal yaitu bukaan bawah berupa pintu, dan bukaan atas berupa bouvenlight. Dominasi bukaan terbanyak berada di sisi timur, hal ini merupakan upaya perancang untuk menangkap angina dari arah timur sebanyak mungkin dan kemudian masuk ke gereja dan di sisi barat hanya terdapat sedikit bukaan karena sisi barat berbatasan dengan talud dengan kemungkinan angina tidak sebanyak sisi timur. Selain bukaan di dalam gereja juga telah disediakan kipas angin di langit langit dan di dinding untuk mempercepat pergerakan udara di dalam geeja jika udara yang masuk melalui bukaan kurang banyak. Dewasa ini gereja sering tidak mampu menampung banyaknya jemaat yang beribadah dan kemudian di sisi timur disediakan selasar untuk para jemaat yang tidak memperoleh tempat didalam gereja. Maka dari itu selasarpun diberi tenda bagi para jemaat untuk melindungi jemaat dari hujan dan panas matahari. Namun di sisi timur selasar yang tadinya merupakan lubang yang berbatasan langsung dengan area luar saat ini dituutup oleh banner gereja yang berguna untuk menghalangi matahari, hal tersebut di sisi lain mengakibatkan udara dari area luar yang berasal dari timur sulit untuk memasuki area gereja.

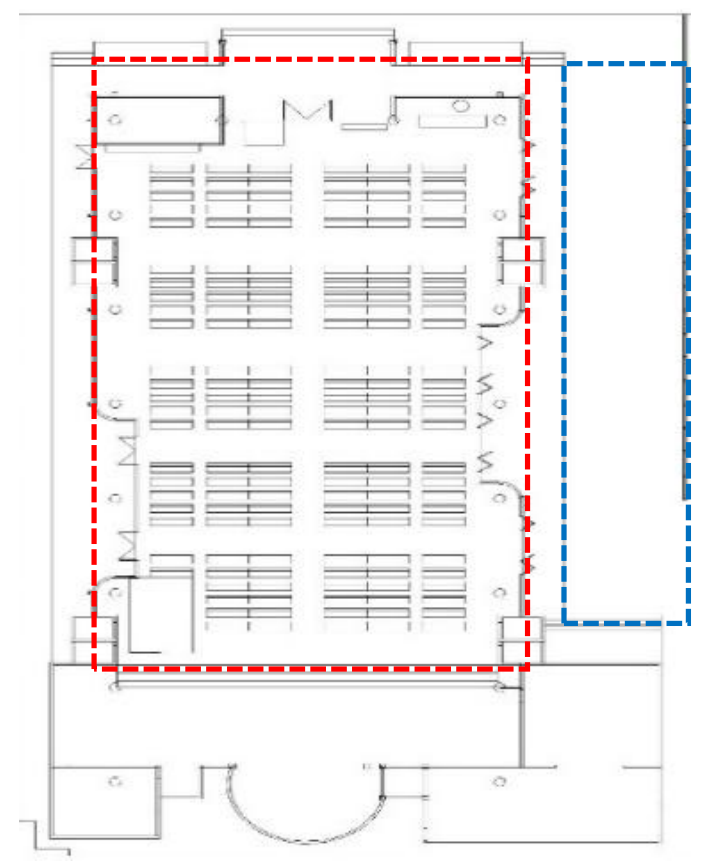

Gambar 6. Denah Gereja Santo Petrus Sambiroto

Gambar 6 menjelaskan denah eksisting dari bangunan gereja persegi berwarna merah merupakan daerah di dalam gereja, sementara biru adalah selasar gereja. Pada Gambar 6 dapat dilihat pula posisi tempat duduk jemaat dan pintu yang ada. 


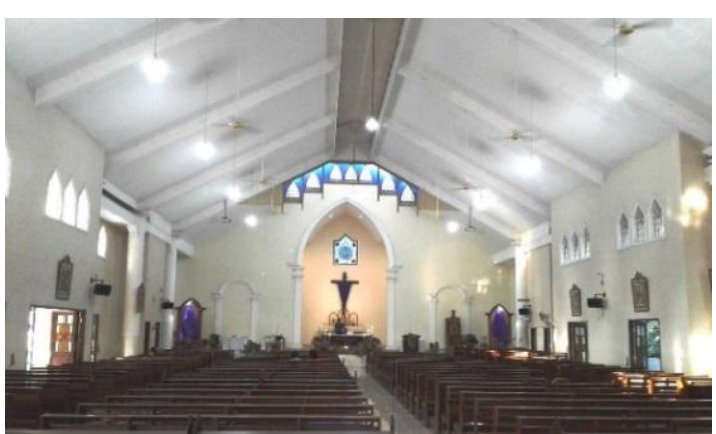

Gambar 7. Kondisi di dalam Gereja Santo Petrus Sambiroto

Gambar 7 menunjukkan kondisi dalam gereja yang memiliki bukaan berupa pintu dan bouvenlight tanpa kaca.

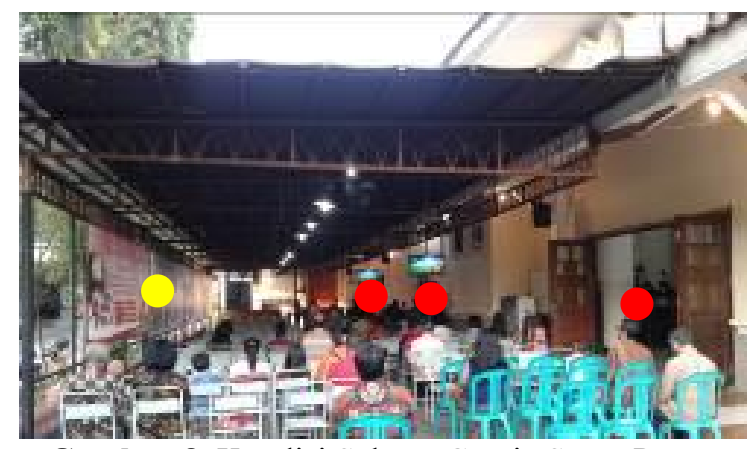

Gambar 8. Kondisi Selasar Gereja Santo Petrus Sambiroto

Gambar 8 merupakan kondisi selasar gereja yang dipasang tenda, gambar tersebut menunjukan sisi timur yang berbatasan dengan area luar dan diberi banner (warna kuning) yang menjadi wind obstacle, sisi barat yang berbatasan dengan area ibadah gereja (juga terdapat pintu yang terbuka saat ibadah, dengan tanda merah), lalu di sisi utara dan timur bagiaan selatan terdapat bukaan menyeluruh.

Gambar 9 merupakan titik titik 1 etak kipas angin di bangunan, dapat dilihat bahwa posisi kipas angin yang berwarna merah adalah kipas angin yang berada di langit langit, sedangkan warna biru adalah kipas angin pada dinding. Keseluruhan kipas tersebut depat mengenai titik ukur penelitian ini. Kipas angin tersebut berguna untuk membantu mengkondisikan udara dengan mempercepat pergerakan udara di bangunan.

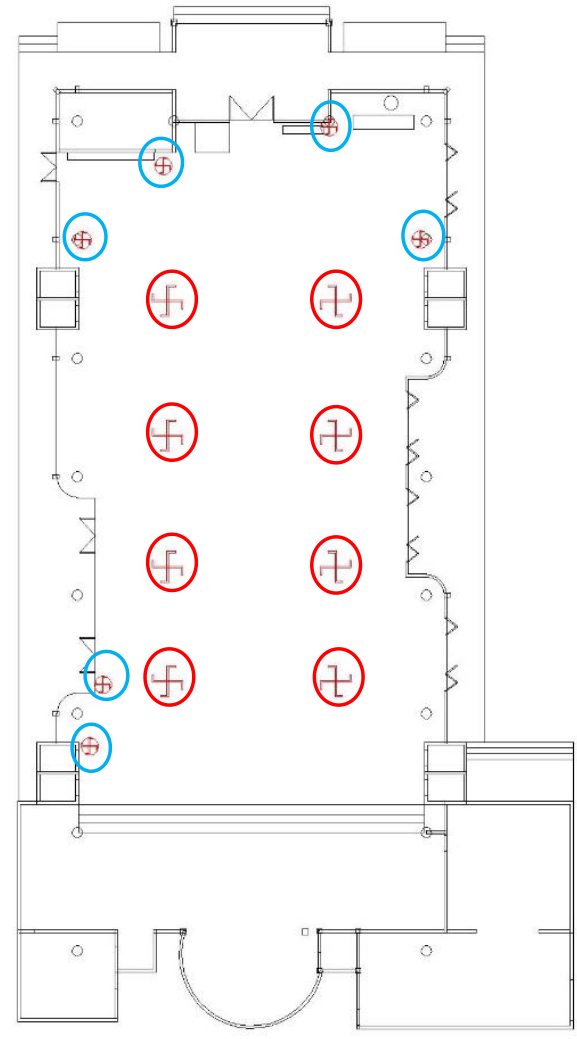

Gambar 9. Titik Kipas Angin Gereja Santo Petrus Sambiroto



Gambar 10. Potongan Gereja Santo Petrus Sambiroto

Gambar 10 merupakan gambar potongan gereja, selasar dan posisi bukaan. Oval berwarna biru menunjukan bukaan berupa pintu yang pada saat ibadah pintu tersebut dibuka, oval berwarna merah adalah bukaan berupa bouvenlight tanpa kaca di dinding bagian atas. 


\subsection{Variabel}

Dalam penelitian ini Variable yang digunakan adalah suhu kering, kelembaban relatif, dan pergerakan udara.

\subsection{Titik Ukur}

Pengukuran dilakukan pada ketinggian $105 \mathrm{~cm}$ dari titik lantai karena di ketinggian tersebutlah paling banyak dalam melakukan aktivitas saat ibadah yaitu duduk, berlutut dan berdiri.

Sedangkan untuk lokasi titik pengukuran dilakukan pada titik di dekat posisi duduk jemaat yang terbagi menjadi 2 yaitu yang berada dekat bukaan dan titik yang tidak berada di dekat bukaan. 2 dasar tersebut sesuai dengan anjuran (SNI 16-7061-2004) tentang Pengukuran Iklim kerja (panas) dengan parameter indeks suhu basah dan bola dimana ketinggian titik ukur berkisar pada ketinggian $1 \mathrm{~m}-1.25 \mathrm{~m}$ dari lantai dan dan di tempat orang banyak melakukan aktivitas, penelitian ini juga difokuskan pada ada tidaknya bukaan di dinding dekat titik ukur.

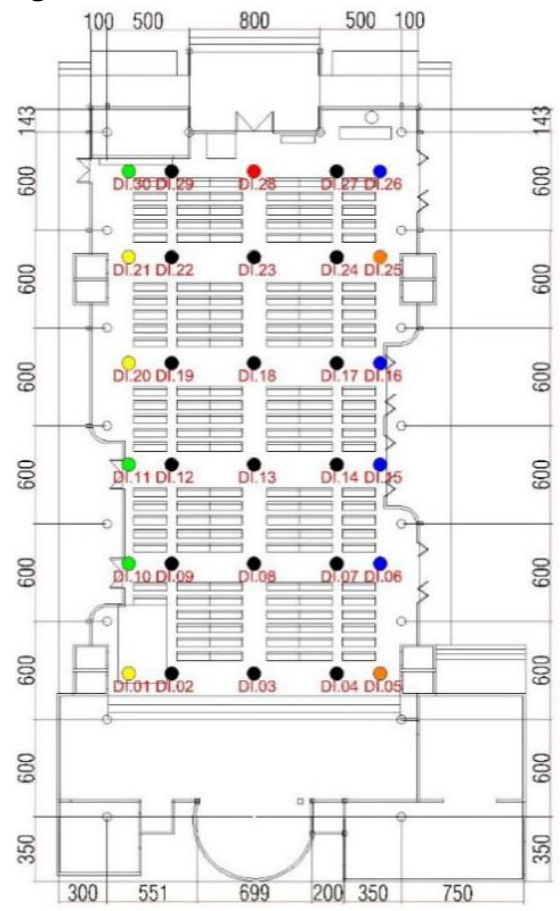

Gambar 11. Titik Ukur di Dalam Gereja Santo Petrus Sambiroto

Gambar 11 merupakan titik ukur di dalam gereja, titik ukur diletakan pada titik yang di sisinya terdapat bukaan dan tidak ada bukaan. Dengan keterangan sebagai berikut. :titik di sisi timur yang dekat dengan bukaan

:titik di sisi barat yang dekat dengan bukaan

:titik di sisi timur yang tidak dekat dengan bukaan

:titik di sisi barat yang tidak dekat dengan bukaan

:titik di sisi utara yang dekat dengan bukaan

:titik ukur yang berada jauh dari dinding.

\subsection{Cara Memperoleh Data}

Penentuan titik ukur adalah berdasarkan ketinggian dan poisisi ukur, untuk ketinggian adalah $105 \mathrm{~cm}$ dari titik lantai karena di titik tersebutlah ketinggian paling banyak dalam melakukan aktivitas saat ibadah yaitu duduk, berlutut dan berdiri.

Sedangkan untuk lokasi titik pengukuran dilakukan pada titik di dekat posisi duduk jemaat yang terbagi menjadi 2 yaitu yang berada dekat bukaan dan titik yang tidak berada di dekat bukaan. Waktu pengukuran adalah pada tanggal 28 April 2019 saat ada misa pukul 06.30WIB ; 08.30 WIB ; dan 18.30 WIB.

Instrumen penelitian merupakan alat alat yang digunakan dalam sebuah penelitian agar penelitian tersebut dapat berjalan dengan baik dan hasilnya dapat dikatakan valid. Instrument penelitian yang digunakan dalam penelitian ini adalah :

a. Alat Tulis dan Kertas untuk mencatatan data lapangan

b. Hygrometer Digital yang merupakan alat yang digunakan untuk mengukur kelembaban dan suhu kering sebuah ruangan.

c. Hotwire Anemometer yang merupakan alat untuk mengukur, pergerakan udara $(\mathrm{m} / \mathrm{s})$, suhu udara $\left({ }^{\circ} \mathrm{C}\right)$.

d. Diagram suhu basah untuk mencari suhu basah yang lalu dimasukan ke diagram kenyamanan termal untuk mencari suhu efektif.

\subsection{Cara Mengolah dan Menganalisa Data}

Dalam mengolah data yang dilakukan adalah hasil ukur lapangan berupa suhu kering, kelembaban relatif dimasukkan kedalam diagram psikometrik untuk dicari suhu basah, 
suhu basah yang telah diketahui kemudian Bersama suhu kering dan pergerakan udara dimasukan ke diagram kenyamanan termal untuk mengetahui suhu efektif.

Cara menganalisa data adalah :

a. Suhu kering, kelembaban relatif, pergerakan udara dan suhu efektif yang teleh didapatkan kemudian dibuat rata rata besaran tiap waktu untuk kemudian dianalisa berdasarkan standard yang ada menurut Szokolay (Kelembaban dan Pergerakan Udara) dan mom (Suhu Efektif).

b. Suhu efektif per titik ukur yang telah didapatkan pada 3 kali waktu ibadah dianalisa menurut standard kenyamanan mom untuk diketahui suhu efektif tersebut memenuhi standard atau tidak.

\section{HASIL DAN PEMBAHASAN}

\subsection{Analisa Variabel Per Waktu}

\subsubsection{Suhu Kering}

Tabel 1. Suhu Kering Per Waktu dan Titik Ukur Kondisi Gereja Ada Ibadah

\begin{tabular}{|c|c|c|c|}
\hline $\begin{array}{c}\text { Titik } \\
\text { Ukur }\end{array}$ & $\begin{array}{c}\text { Suhu } \\
\text { Kering } \\
\left({ }^{\circ} \mathrm{C}\right) \text { Pukul } \\
\text { 06.30 WIB }\end{array}$ & $\begin{array}{c}\text { Suhu } \\
\text { Kering }\left({ }^{\circ} \mathrm{C}\right) \\
\text { Pukul 08.30 } \\
\text { WIB } \\
\end{array}$ & $\begin{array}{c}\text { Suhu } \\
\text { Kering }\left({ }^{\circ} \mathrm{C}\right) \\
\text { Pukul } \\
\text { 18.30 WIB } \\
\end{array}$ \\
\hline DI.01 & 27.50 & 28.60 & 30.60 \\
\hline DI.02 & 27.5 & 28.5 & 30.7 \\
\hline DI.03 & 27.8 & 28.5 & 30.6 \\
\hline DI.04 & 27.5 & 28.6 & 30.6 \\
\hline DI.05 & 27.6 & 28.6 & 30.7 \\
\hline DI.06 & 27.2 & 28.2 & 29.8 \\
\hline DI.07 & 27.7 & 28.3 & 30.8 \\
\hline DI.08 & 27.1 & 28.3 & 30.7 \\
\hline DI.09 & 27.1 & 28.2 & 30.7 \\
\hline DI.10 & 27 & 28.3 & 30.7 \\
\hline DI.11 & 27.9 & 28.2 & 30.8 \\
\hline DI.12 & 27.3 & 28.4 & 30.6 \\
\hline DI.13 & 28.1 & 28.6 & 30.6 \\
\hline DI.14 & 27.1 & 28.3 & 30.2 \\
\hline DI.15 & 27 & 28.5 & 30.5 \\
\hline DI.16 & 27 & 28.6 & 30.7 \\
\hline DI.17 & 27.3 & 28.7 & 30 \\
\hline DI.18 & 27.4 & 28.6 & 30 \\
\hline DI.19 & 27.4 & 28.6 & 30.5 \\
\hline DI.20 & 27.5 & 28.7 & 30.9 \\
\hline DI.21 & 27.7 & 28.7 & 30.9 \\
\hline DI.22 & 27.3 & 28.6 & 30.8 \\
\hline DI.23 & 27.6 & 28.8 & 30.7 \\
\hline DI.24 & 27.6 & 28.7 & 30.5 \\
\hline DI.25 & 27.8 & 28.3 & 30.4 \\
\hline DI.26 & 27.2 & 28.1 & 29.8 \\
\hline DI.27 & 27.4 & 28.5 & 30 \\
\hline DI.28 & 27 & 28.1 & 29.2 \\
\hline
\end{tabular}

\begin{tabular}{|c|c|c|c|}
\hline $\begin{array}{c}\text { Titik } \\
\text { Ukur }\end{array}$ & $\begin{array}{c}\text { Suhu } \\
\text { Kering } \\
\left({ }^{\circ} \mathbf{C}\right) \text { Pukul } \\
\mathbf{0 6 . 3 0} \text { WIB }\end{array}$ & $\begin{array}{c}\text { Suhu } \\
\text { Kering }\left({ }^{\circ} \mathbf{C}\right) \\
\text { Pukul 08.30 } \\
\text { WIB }\end{array}$ & $\begin{array}{c}\text { Suhu } \\
\text { Kering }\left({ }^{\circ} \mathbf{C}\right) \\
\text { Pukul } \\
\mathbf{1 8 . 3 0} \text { WIB }\end{array}$ \\
\hline DI.29 & 27.5 & 28.6 & 29.7 \\
\hline DI.30 & 26 & 28.3 & 29.8 \\
\hline $\begin{array}{c}\text { Rata - } \\
\text { Rata }\end{array}$ & 27.37 & 28.47 & 30.41 \\
\hline
\end{tabular}

Data pada tabel 1 jika rata ratanya divisualkan dalam bentuk diagram seperti pada Gambar 12, adalah sebagai berikut :

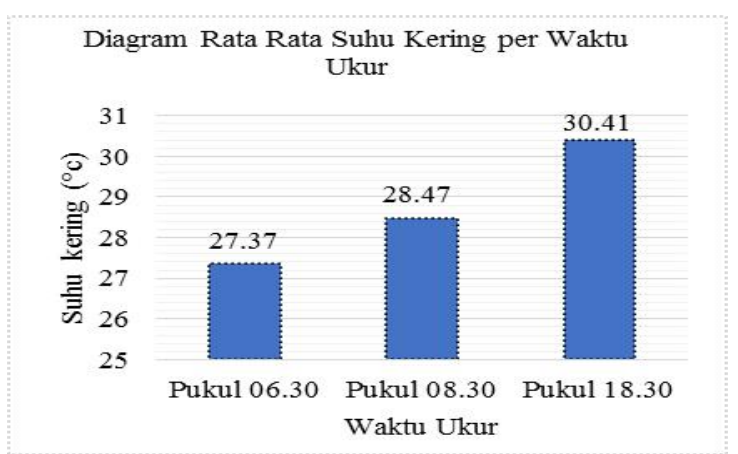

Gambar 12. Diagram Rata-rata Suhu Kering pada Setiap Waktu Ukur

Dari diagram pada Gambar 12 dapat dilihat bahwa suhu kering mengalami kenaikan dari waktu ke waktu di setiap titik ukurnya. Pada pukul 06.30 WIB suhu rata ratanya adalah $27.37^{\circ} \mathrm{C}$ lalu naik sebesar satu derajat menuju $28.46{ }^{\circ} \mathrm{C}$ pada pukul $8.30 \mathrm{WIB}$, kemudian pada pukul 18.30 menjadi $30.41^{\circ} \mathrm{C}$.

Suhu yang naik dari pukul 06.30 WIB ke 08.30 WIB tidak terlalu tinggi disebabkan oleh adanya matahari yang mulai naik lalu dari 08.30 WIB ke 18.30 WIB naik kurang lebih 3 derajat walaupun matahari sudah tenggelam, hal ini dikarenakan timelag yang ada di dalam bangunan jadi walaupun matahari sudah tenggelam suhu didalam masih tinggi.

Jadi suhu kering di dalam bangunan pada saat misa ini dipengaruhi yang pertama oleh ada tidaknya matahari terlihat pada pukul 06.30 WIB sampai 08.30 WIB. yang kedua adalah karena adanya timelag, walaupun matahari sudah turun namun di dalam bangunan suhu masih tinggi pada pukul 18.30 WIB.

\subsubsection{Kelembaban Relatif}

Tabel 2. Kelembaban Per Waktu dan Titik Ukur Kondisi Gereja Ada Ibadah 


\begin{tabular}{|c|c|c|c|}
\hline Titik & $\begin{array}{c}\text { Kelembab- } \\
\text { an Relatif } \\
\text { (\%) Pukul } \\
\text { 06.30 WIB }\end{array}$ & $\begin{array}{c}\text { Kelembab- } \\
\text { an Relatif } \\
\text { (\%) Pukul } \\
\mathbf{0 8 . 3 0} \text { WIB }\end{array}$ & $\begin{array}{c}\text { Kelem- } \\
\text { baban } \\
\text { Relatif } \\
\text { (\%) } \\
\text { Pukul } \\
\mathbf{1 8 . 3 0} \\
\text { WIB }\end{array}$ \\
\hline DI.01 & 77 & 82 & 84 \\
\hline DI.02 & 77 & 82 & 84 \\
\hline DI.03 & 77 & 83 & 84 \\
\hline DI.04 & 79 & 84 & 85 \\
\hline DI.05 & 78 & 84 & 84 \\
\hline DI.06 & 75 & 84 & 84 \\
\hline DI.07 & 76 & 83 & 84 \\
\hline DI.08 & 77 & 82 & 83 \\
\hline DI.09 & 75 & 82 & 84 \\
\hline DI.10 & 76 & 81 & 82 \\
\hline DI.11 & 77 & 82 & 83 \\
\hline DI.12 & 79 & 82 & 86 \\
\hline DI.13 & 77 & 83 & 85 \\
\hline DI.14 & 78 & 84 & 85 \\
\hline DI.15 & 77 & 83 & 84 \\
\hline DI.16 & 77 & 84 & 84 \\
\hline DI.17 & 79 & 84 & 85 \\
\hline DI.18 & 78 & 84 & 85 \\
\hline DI.19 & 77 & 84 & 87 \\
\hline DI.20 & 78 & 85 & 87 \\
\hline DI.21 & 79 & 83 & 86 \\
\hline DI.22 & 77 & 83 & 86 \\
\hline DI.23 & 70 & 84 & 87 \\
\hline DI.24 & 77 & 82 & 86 \\
\hline DI.25 & 77 & 83 & 85 \\
\hline DI.26 & 76 & 82 & 85 \\
\hline DI.27 & 77 & 82 & 83 \\
\hline DI.28 & 75 & 81 & 84 \\
\hline DI.29 & 77 & 82 & 84 \\
\hline DI.30 & 76 & 83 & 84 \\
\hline Rata - & 76.83 & 82.93 & 84.66 \\
\hline Rata & & & \\
\hline & & & \\
\hline
\end{tabular}

Data pada tabel 2, jika rata-rata hasil divisualkan dalam bentuk diagram adalah seperti pada Gambar 13. Dari diagram pada Gambar 13 dapat dilihat bahwa kelembaban relatif pada pukul 06.30 WIB rata rata adalah $76,83 \%$. Untuk pukul 08.30 WIB kelembaban mencapai $82,93 \%$ lalu pada pukul $18.30 \mathrm{WIB}$ adalah $84,66 \%$.

Kelembaban pada pukul 06.30 WIB rata rata adalah $76.83 \%$, hal ini disebabkan oleh keadaan yang masih pagi sehingga kelembaban tidak terlalu tinggi. Kondisi ini sudah melampau kelembaban yang dianjurkan menurut (S.V Szokolay, 1980) yaitu 30\%-65\% akan tetapi tidak melebihi batas toleransi yaitu $77 \%$.

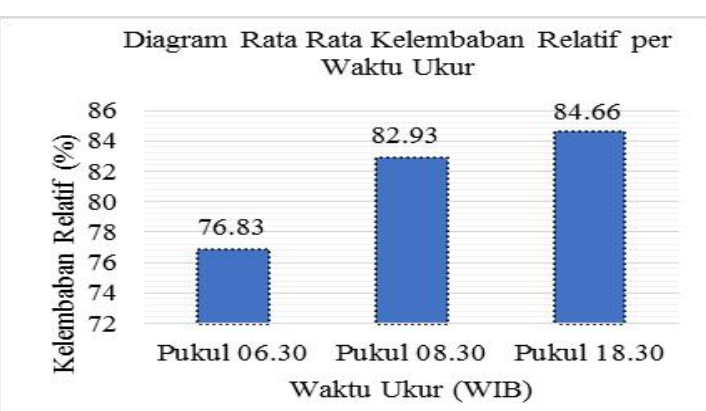

Gambar 13. Diagram Rata-rata Kelembaban Relatif pada Setiap Waktu Ukur.

Kelembaban pada pukul 08.30 WIB rata rata adalah $82,93 \%$, kondisi ini sudah melampaui kelembaban yang dianjurkan menurut (S.V Szokolay, 1980) yaitu $30 \%-65 \%$ dan juga melebihi batas toleransi yaitu $77 \%$. Kelembaban pada pukul 18.30 WIB rata rata adalah 84,66\%, kondisi ini sudah melampaui kelembaban yang dianjurkan menurut (S.V Szokolay, 1980) yaitu 30\% - 65\% dan juga melebihi batas toleransi yaitu $77 \%$.. Kelembaban yang tinggi ini dikarenakan banyaknya jemaat yang melakukan misa di gereja yang menjadikan kandungan uap di udara meningkat karena penguapan dari keringat jemaat.

\subsubsection{Pergerakan Udara}

Tabel 3. Pergerakan Udara Per Waktu dan Titik Ukur Kondisi Gereja Ada Ibadah

\begin{tabular}{|c|c|c|c|}
\hline Titik Ukur & $\begin{array}{c}\text { Pergerak- } \\
\text { an Udara } \\
\text { (m/s) } \\
\text { Pukul } \\
\mathbf{0 6 . 3 0} \text { WIB }\end{array}$ & $\begin{array}{c}\text { Pergerak- } \\
\text { an Udara } \\
\mathbf{( m / s )} \\
\text { Pukul } \\
\mathbf{0 8 . 3 0} \text { WIB }\end{array}$ & $\begin{array}{c}\text { Perge- } \\
\text { rakan } \\
\text { Udara } \\
\mathbf{( m / s )} \\
\text { Pukul } \\
\mathbf{1 8 . 3 0} \\
\text { WIB }\end{array}$ \\
\hline DI.01 & 0.36 & 0.47 & 0.23 \\
\hline DI.02 & 0.39 & 0.52 & 0.4 \\
\hline DI.03 & 0.64 & 0.22 & 0.18 \\
\hline DI.04 & 0.32 & 0.38 & 0.19 \\
\hline DI.05 & 0.27 & 0.24 & 0.21 \\
\hline DI.06 & 0.67 & 0.57 & 0.72 \\
\hline DI.07 & 0.63 & 0.39 & 0.22 \\
\hline DI.08 & 0.65 & 0.21 & 0.5 \\
\hline DI.09 & 0.75 & 0.22 & 0.54 \\
\hline DI.10 & 0.44 & 0.25 & 0.56 \\
\hline DI.11 & 0.54 & 0.35 & 0.45 \\
\hline DI.12 & 0.65 & 0.68 & 0.67 \\
\hline DI.13 & 0.74 & 0.52 & 0.64 \\
\hline DI.14 & 0.75 & 0.69 & 0.58 \\
\hline
\end{tabular}




\begin{tabular}{|c|c|c|c|}
\hline Titik Ukur & $\begin{array}{c}\text { Pergerak- } \\
\text { an Udara } \\
\mathbf{( m / s )} \\
\text { Pukul } \\
\mathbf{0 6 . 3 0 ~ W I B ~}\end{array}$ & $\begin{array}{c}\text { Pergerak- } \\
\text { an Udara } \\
\mathbf{( m / s )} \\
\text { Pukul } \\
\mathbf{0 8 . 3 0} \text { WIB }\end{array}$ & $\begin{array}{c}\text { Perge- } \\
\text { rakan } \\
\text { Udara } \\
\text { (m/s) } \\
\text { Pukul } \\
\mathbf{1 8 . 3 0} \\
\text { WIB }\end{array}$ \\
\hline DI.15 & 0.75 & 0.78 & 0.68 \\
\hline DI.16 & 0.66 & 0.74 & 0.69 \\
\hline DI.17 & 0.67 & 0.38 & 0.56 \\
\hline DI.18 & 0.57 & 0.34 & 0.41 \\
\hline DI.19 & 0.34 & 0.56 & 0.34 \\
\hline DI.20 & 0.45 & 0.51 & 0.47 \\
\hline DI.21 & 0.46 & 0.21 & 0.32 \\
\hline DI.22 & 0.46 & 0.56 & 0.34 \\
\hline DI.23 & 0.74 & 0.89 & 0.43 \\
\hline DI.24 & 0.47 & 0.76 & 0.45 \\
\hline DI.25 & 0.35 & 0.35 & 0.47 \\
\hline DI.26 & 0.75 & 0.76 & 0.76 \\
\hline DI.27 & 0.23 & 0.53 & 0.31 \\
\hline DI.28 & 0.78 & 0.89 & 0.98 \\
\hline DI.29 & 0.61 & 0.31 & 0.83 \\
\hline DI.30 & 0.65 & 0.56 & 0.67 \\
\hline RATA & 0.56 & 0.50 & 0.50 \\
\hline RATA & & & \\
\hline & & & \\
\hline
\end{tabular}

Hasil pada data yang ditampilkan tabel 3 jika rata-rata divisualkan dalam bentuk diagram seperti pada Gambar 14.

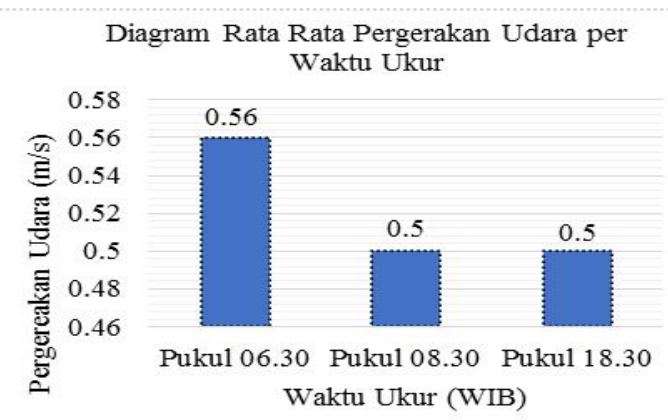

Gambar 14. Diagram Rata-rata Pergerakan Udara pada Setiap Waktu Ukur

Pada tabel 3 menunjukkan pergerakan udara. Pada pukul 06.30 WIB memiliki rata rata 0.56 $\mathrm{m} / \mathrm{s}$ lalu pada pukul menurun menjadi $0.50 \mathrm{~m} / \mathrm{s}$ pada pukul 08.30 WIB. lalu kemudian pada pukul 18.30 WIB kecepatan angin adalah 0.50 $\mathrm{m} / \mathrm{s}$.

Pergerakan udara di dalam bangunan relatif tidak mengalami perubahan yang berarti tiap waktunya Jika dilihat dari standard menurut (S.V Szokolay, 1980) maka pada pukul 06.30WIB pergerakan udara $0.56 \mathrm{~m} / \mathrm{s}$ masuk kategori dapat dirasakan kulit yaitu $0.50 \mathrm{~m} / \mathrm{s}$ $1 \mathrm{~m} / \mathrm{s}$, sedangkan pukul 08.30 WIB dan 18.30 WIB pergerakan udara $0.50 \mathrm{~m} / \mathrm{s}$ masuk ke 2 kategori yaitu nyaman yang berkisar 0.25 $\mathrm{m} / \mathrm{s}-0.50 \mathrm{~m} / \mathrm{s}$. dan pergerakan udara dapat dirasakan kulit berkisar $0.50 \mathrm{~m} / \mathrm{s}-1 \mathrm{~m} / \mathrm{s}$. Jadi dari ketiga hasil tersebut menurut (S.V Szokolay, 1980) telah memenuhi standard karena berada diatas $0.2 \mathrm{~m} / \mathrm{s}$.

\subsubsection{Suhu Efektif}

Tabel 4. Suhu Efektif Per Waktu dan Titik Ukur Kondisi Gereja Ada Ibadah

\begin{tabular}{|c|c|c|c|}
\hline Titik Ukur & $\begin{array}{c}\text { Suhu } \\
\text { Efektif } \\
\left({ }^{\circ} \mathrm{C}\right) \\
\text { Pukul } \\
\text { 06.30 } \\
\text { WIB }\end{array}$ & $\begin{array}{c}\text { Suhu } \\
\text { Efektif } \\
\left({ }^{\circ} \mathrm{C}\right) \\
\text { Pukul } \\
\text { 08.30 } \\
\text { WIB }\end{array}$ & $\begin{array}{c}\text { Suhu } \\
\text { Efektif } \\
\left({ }^{\circ} \mathrm{C}\right) \\
\text { Pukul } \\
18.30 \\
\text { WIB }\end{array}$ \\
\hline DI.01 & 24.01 & 24.96 & 28.71 \\
\hline DI.02 & 23.82 & 24.72 & 28 \\
\hline DI.03 & 23.51 & 26.12 & 29.15 \\
\hline DI.04 & 24.28 & 25.41 & 29.22 \\
\hline DI.05 & 24.59 & 26.16 & 29.1 \\
\hline DI.06 & 22.87 & 24.4 & 26.03 \\
\hline DI.07 & 23.4 & 24.98 & 28.9 \\
\hline DI.08 & 22.87 & 25.92 & 27.57 \\
\hline DI.09 & 22.65 & 25.74 & 27.33 \\
\hline DI.10 & 23.27 & 25.54 & 27.3 \\
\hline DI.11 & 23.65 & 25.28 & 27.84 \\
\hline DI.12 & 23.11 & 24.27 & 27.51 \\
\hline DI.13 & 23.63 & 24.89 & 27.41 \\
\hline DI.14 & 22.72 & 24.26 & 26.94 \\
\hline DI.15 & 22.61 & 24.28 & 27.06 \\
\hline DI.16 & 22.77 & 24.51 & 27.34 \\
\hline DI.17 & 23.07 & 24.57 & 26.71 \\
\hline DI.18 & 23.33 & 25.58 & 27.12 \\
\hline DI.19 & 24.01 & 24.87 & 28.16 \\
\hline DI.20 & 23.74 & 25.08 & 28.59 \\
\hline DI.21 & 23.93 & 26.42 & 28.96 \\
\hline DI.22 & 23.5 & 24.8 & 28.71 \\
\hline DI.23 & 22.95 & 24.54 & 28.38 \\
\hline DI.24 & 23.73 & 24.47 & 27.48 \\
\hline DI.25 & 24.31 & 25.14 & 27.49 \\
\hline DI.26 & 22.76 & 24.14 & 26.72 \\
\hline DI.27 & 24.63 & 24.69 & 27.28 \\
\hline DI.28 & 23.4 & 23.71 & 24.92 \\
\hline DI.29 & 23.3 & 25.57 & 25.74 \\
\hline DI.30 & 23.64 & 24.47 & 27.08 \\
\hline RATA RATA & 23.45 & 24.98 & 27.5 \\
\hline
\end{tabular}

Data pada tabel 4, jika diterjemahkan dalam bentuk diagram adalah seperti pada Gambar 15 . 


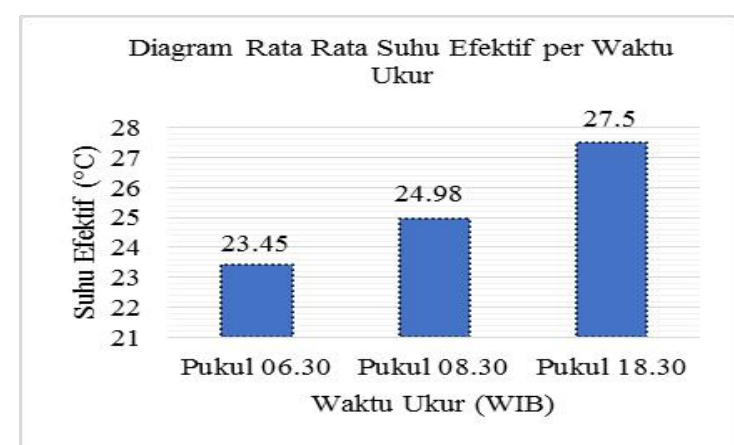

Gambar 15. Diagram Rata-rata Suhu Efektif pada Setiap Waktu Ukur

Suhu Efektif di setiap waktu pengukuan selalu mengalami peningkatan. Suhu rata rata pada pukul 06.30 WIB adalah sebesar $23.45^{\circ} \mathrm{C}$, lalu pada pukul 08.30 WIB meningkat menjadi $24.98^{\circ} \mathrm{C}$, dan pukul 18.30 WIB adalah sebesar $27.5^{\circ} \mathrm{C}$.

Pada pukul 06.30 WIB kondisi masih pagi suhu efektif rata rata $23.45^{\circ} \mathrm{C}$ jika dilihat pada tabel suhu kering, kelembaban dan pergerakan udara maka pada pukul 06.30 WIB terdapat suhu kering sebesar $27.37^{\circ} \mathrm{C}$, kelembaban sebesar $76.83 \%$ dan kecepatan angin $0.56 \mathrm{~m} / \mathrm{s}$. kecepatan udara ini adalah hal yang paling berpengaruh, karena di saat suhu kering 27.37 yang dimana melebihi batas karena lebih dari $27.1^{\circ} \mathrm{C}$ dan kelembaban sebesar $76.83 \%$ yang hampir melebihi batas toleransi sebesar $77 \%$, adanya pergerakan udara sebesar $0.56 \mathrm{~m} / \mathrm{s}$ ini telah memenuhi syarat sebesar lebih dari 0.2 $\mathrm{m} / \mathrm{s}$ dan dapat menyapu uap air yang ada di tubuh manusia menyebabkan suhu efektif masih berada di batas nyaman yaitu sebesar $23.45^{\circ} \mathrm{C}$ dan masuk ke kriteria nyaman optimal $\left(22.8^{\circ} \mathrm{C}-25.8^{\circ} \mathrm{C}\right)$ menurut mom dan SNI.

Pada pukul 08.30 WIB kondisi masih pagi suhu efektif rata rata $24.98^{\circ} \mathrm{C}$ jika dilihat pada table suhu kering, kelembaban dan pergerakan udara maka pada pukul 08.30 WIB terdapat suhu kering yang sebesar $28.46^{\circ} \mathrm{C}$, kelembaban sebesar $82.93 \%$ dan kecepatan angin $0.50 \mathrm{~m} / \mathrm{s}$. Kecepatan udara ini adalah hal yang paling berpengaruh, karena di saat suhu kering $28.46^{\circ} \mathrm{C}$ sudah meleebihi ambang sebesar $27.1^{\circ} \mathrm{C}$ dan kelembaban sebesar $82.93 \%$ melebihi batas toleransi sebesar $77 \%$. Namun angin pergerakan udara sebesar $0.50 \mathrm{~m} / \mathrm{s}$ ini telah memenuhi syarat sebesar lebih dari $0.2 \mathrm{~m} / \mathrm{s}$ dan dapat menyapu uap air yang ada di tubuh manusia menyebabkan suhu efektif masih berada di batas nyaman yaitu sebesar $24.98^{\circ} \mathrm{C}$ dan masuk ke kriteria nyaman optimal $\left(22,8^{\circ} \mathrm{C}-\right.$ $25.8^{\circ} \mathrm{C}$ ) menurut mom dan SNI.

Pada pukul 18.30 WIB kondisi masih pagi suhu rata rata $27.59^{\circ} \mathrm{C}$. Jika dilihat pada table seuhu kering, kelembaban dan pergerakan udara maka pada pukul 18.30 WIB suhu kering yang sebesar $30.41^{\circ} \mathrm{C}$, kelembaban sebesar $84.66 \%$ dan kecepatan angin $0.50 \mathrm{~m} / \mathrm{s}$. Kecepatan udara ini adalah hal yang paling berpengaruh, karena di saat suhu kering $30.41{ }^{\circ} \mathrm{C}$ sudah melebihi ambang sebsar $27.1^{\circ} \mathrm{C}$ dan kelembaban sebesar $84.66 \%$ yang juga melebihi batas toleransi sebesar $77 \%$. Namun pergerakan udara sebesar $0.50 \mathrm{~m} / \mathrm{s}$ yang dimana telah memenuhi syarat lebih dari $0.2 \mathrm{~m} / \mathrm{s}$ masih belum mampu menciptakan suhu yang berada di batas nyaman menurut mom dan SNI yaitu tidak lebih dari $27.1^{\circ} \mathrm{C}$.

Dari penjabaran diatas dapat disimpulkan bahwa suhu kering dan kelembaban yang sudah melebihi batas nyaman menurut mom dapat diimbangi dengan pergerakan udara yang sesuai agar dapat menciptakan suhu efektif yang tetap nyaman.

\subsection{Analisa Suhu Efektif Berdasarkan Titik Ukur Per Waktu}

Analisa suhu efektif dilakukan pada titik titik yang berada di sisi sisi bangunan yang didekatnya terdapat bukan dan tidak terdapat bukaan

\subsubsection{Suhu Efektif Pukul 06.30 WIB}

Pada Gambar 16 merupakan data suhu efektif yang didapat dari pengukuran lapangan pada pukul 06.30 WIB.

Diagram batang terbagi menjadi 2 garis besar yaitu diagram batang "berwarna seklain hitam" merupakan titik ukur di yang berada berdekatan dengan dinding yang dimana titik inilah yang akan dianalisa terkait ada tidak bukaan di sisinya, sedangkan diagram batang yang berwarna hitam adalah titik ukur yang berada jauh dari dinding dan tidak masuk dalam analisa karena titik tersebut lebih dekat dengan kipas angin daripada bukaan. Terkait 2 hal tersebut kaitannya dengan rata rata kondisi suhu di dalam bangunan secara keseluruhan 
(baik berada di dekat dinding maupun tidak telah dibahas pada sub bab nomor 3.1.4 tentang Suhu Efektif. Sedangkan keterangan untuk warna tersebut dibahas dalam subab 2.3 tentang Titik Ukur.

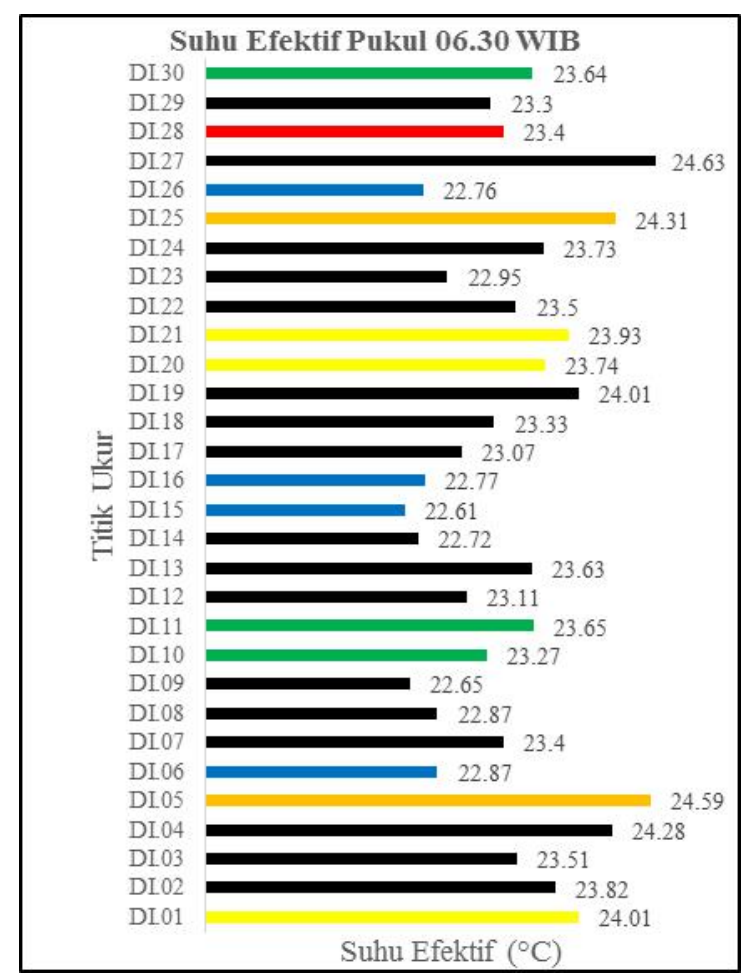

Gambar 16. Diagram Suhu Efektif per Titik Ukur Pukul 06.30 WIB Kondisi Ada Ibadah

Analisa terkait diagram batang yang berwarna selain hitam (berada di dekat dinding kaitannya dengan ada tidaknya bukaan) adalah sebagai berikut : a) sisi timur yang dekat bukaan memiliki suhu yaitu titik DI.06 sebesar $22.87{ }^{\circ} \mathrm{C}$; titik DI.15 sebesar $22.61^{\circ} \mathrm{C}$; titik DI.16 sebesar $22.77^{\circ} \mathrm{C}$ titik DI.26 sebesar $22.76^{\circ} \mathrm{C}$. b) sisi barat yang dekat dengan bukaan memiliki suhu efektif yaitu titi DI.10 sebesar $23.27^{\circ} \mathrm{C}$; DI.11 sebesar $23.56^{\circ} \mathrm{C}$; DI.30 sebesar $23.64^{\circ} \mathrm{C}$. c) sisi timur yang di sisinya tidak terdapat bukaan memiliki suhu efektif yaitu DI. 01 sebesar $24.01^{\circ} \mathrm{C}$; titik DI.20 sebesar $23.74^{\circ} \mathrm{C}$; titik DI.21 sebesar $23.93^{\circ} \mathrm{C}$. d) sisi barat yang di sisinya tidak terdapat bukaan memiliki suhu efektif yaitu titik DI.5 sebesar $24.59^{\circ} \mathrm{C} \quad$ DI. 25 sebesar $24.31^{\circ} \mathrm{C}$. e) sisi utara yang dekat bukaan mempunyai suhu efektif sebesar DI.28 sebesar $23.40^{\circ} \mathrm{C}$.

Di poin a) yaitu titik di sisi timur yang di dekatnya terdapat bukaan memiliki suhu efektif DI.6 sebesar $22.87^{\circ} \mathrm{C}$; titik DI.15 sebesar $22.61^{\circ} \mathrm{C}$; titik DI.16 sebesar $22.77^{\circ} \mathrm{C}$ titik DI.26 sebesar $22.76^{\circ} \mathrm{C}$. suhu efektif yang rendah ini dikarenakan posisi yang dekat dengan bukaan titik ini mempunyai suhu yang masuk kriteria sejuk nyaman dan nyaman optimal menurut mom. b) yaitu titik di sisi barat yang di dekatnya terdapat bukaan memiliki suhu efektif DI.10 sebesar $23.27^{\circ} \mathrm{C}$; DI.11 sebesar $23.56^{\circ} \mathrm{C}$; DI.30 sebesar $23.64^{\circ} \mathrm{C}$, suhu efektif yang rendah ini dikarenakan posisi yang dekat dengan bukaan titik ini mempunyai suhu yang masuk kriteria nyaman optimal menurut mom. c) yaitu titik di sisi timur yang di dekatnya tidak terdapat bukaan memiliki suhu efektif DI. 01 sebesar $24.01{ }^{\circ} \mathrm{C}$; titik DI.20 sebesar $23.74^{\circ} \mathrm{C}$; titik DI.21 sebesar $23.93^{\circ} \mathrm{C}$, suhu efektif yang rendah ini dikarenakan posisi yang dekat dengan bukaan titik ini mempunyai suhu yang masuk kriteria nyaman optimal menurut mom. d) yaitu titik di sisi timur yang di dekatnya tidak terdapat bukaan memiliki suhu efektif DI.05 sebesar $24.59^{\circ} \mathrm{C}$ DI.25 sebesar $24.31^{\circ} \mathrm{C}$ suhu efektif yang rendah ini dikarenakan posisi yang dekat dengan bukaan titik ini mempunyai suhu yang masuk kriteria nyaman optimal menurut mom. e) yaitu titik di sisi utara yang didekatnya terdapat bukaan memiliki suhu efektif DI.28 sebesar $23.40^{\circ} \mathrm{C}$. suhu efektif yang rendah ini dikarenakan posisi yang dekat dengan bukaan titik ini mempunyai suhu yang masuk kriteria nyaman optimal menurut mom.

Jika data tersebut dibandingkan dengan standard kenyamanan menurut mom yang memiliki batas kenyamanan antara $20.5^{\circ} \mathrm{C}$ $27.1^{\circ} \mathrm{C}$ maka keseluruhan titik yang dijadikan titik pengukuran telah memenuhi standard kenyamanan suhu efektif menurut mom karena terletak diatas $20.5^{\circ} \mathrm{C}$ dan dibawah $27.1^{\circ} \mathrm{C}$. Akan tetapi titik titik yang berdekatan dengan bukaan memiliki suhu efektif yang lebih rendah dibanding titik yang tidak terdapat bukaan.

\subsubsection{Suhu Efektif Pukul 08.30 WIB}

Gambar 17 merupakan data suhu efektif yang didapat dari pengukuran lapangan pada pukul 08.30 WIB. 




Gambar 17. Diagram Suhu Efektif per Titik Ukur Pukul 08.30 WIB Kondisi Ada Ibadah

Diagram batang terbagi menjadi 2 garis besar yaitu diagram batang "berwarna seklain hitam" merupakan titik ukur di yang berada berdekatan dengan dinding yang dimana titik inilah yang akan dianalisa terkait ada tidak bukaan di sisinya, sedangkan diagram batang yang berwarna hitam adalah titik ukur yang berada jauh dari dinding dan tidak masuk dalam analisa karena titik tersebut lebih dekat dengan kipas angin daripada bukaan. Terkait 2 hal tersebut kaitannya dengan rata rata kondisi suhu di dalam bangunan secara keseluruhan (baik berada di dekat dinding maupun tidak telah dibahas pada sub bab nomor 3.1.4 tentang Suhu Efektif. Sedangkan keterangan untuk warna tersebut dibahas dalam subab 2.3 tentang Titik Ukur.

Analisa terkait diagram batang yang berwarna selain hitam (berada di dekat dinding kaitannya dengan ada tidaknya bukaan) adalah sebagai berikut : a) sisi timur yang dekat bukaan memiliki suhu yaitu titik DI.6 sebesar $24.40^{\circ} \mathrm{C} \quad{ }^{\circ} \mathrm{C}$; titik DI. 15 sebesar $24.28^{\circ} \mathrm{C}$; titik DI.16 sebesar $24.51^{\circ} \mathrm{C}$; titik DI.26 sebesar $24.14^{\circ} \mathrm{C}$. b) sisi barat yang dekat dengan bukaan memiliki suhu efektif yaitu titik DI.10 sebesar $25.54^{\circ} \mathrm{C}$; DI.11 sebesar $25.28^{\circ} \mathrm{C}$; DI.30 sebesar $24.47^{\circ} \mathrm{C}$. c) sisi timur yang di sisinya tidak terdapat bukaan memiliki suhu efektif yaitu DI. 01 sebesar $24.96^{\circ} \mathrm{C}$; titik DI. 20 sebesar $25.08^{\circ} \mathrm{C}$; titik
DI.21 sebesar $26.42^{\circ} \mathrm{C}$. d) sisi barat yang di sisinya tidak terdapat bukaan memiliki suhu efektif yaitu titik DI.5 sebesar $26.16^{\circ} \mathrm{C}$ dan DI.25 sebesar $25.14^{\circ} \mathrm{C}$. e) sisi utara yang dekat bukaan mempunyai suhu efektif yaitu titik DI.28 sebesar $23.71^{\circ} \mathrm{C}$.

Di poin a) yaitu titik di sisi timur yang di dekatnya terdapat bukaan memiliki suhu efektif DI.06 sebesar $24.40^{\circ} \mathrm{C}$; DI.15 sebesar $24.28^{\circ} \mathrm{C}$; DI.16 sebesar $24.51^{\circ} \mathrm{C}$; DI.26 sebesar $24.14^{\circ} \mathrm{C}$. suhu efektif yang rendah ini dikarenakan posisi yang dekat dengan bukaan titik ini mempunyai suhu yang masuk kriteria nyaman optimal menurut mom dan SNI. b) yaitu titik di sisi barat yang di dekatnya terdapat bukaan memiliki suhu efektif DI.10 sebesar $25.54^{\circ} \mathrm{C}$; DI.11 sebesar $25.28^{\circ} \mathrm{C}$; DI.30 sebesar $24.47^{\circ} \mathrm{C}$. suhu efektif yang rendah ini dikarenakan posisi yang dekat dengan bukaan titik ini mempunyai suhu yang masuk kriteria nyaman optimal menurut mom dan SNI. c) yaitu titik di sisi timur yang di dekatnya tidak terdapat bukaan memiliki suhu efektif DI. 01 sebesar $24.96{ }^{\circ} \mathrm{C}$; titik DI.20 sebesar $25.08^{\circ} \mathrm{C}$; titik DI.21 sebesar $26.42^{\circ} \mathrm{C}$, suhu efektif pada titik DI.01 dan DI.20 masuk ke dalam kriteria nyaman optimal, tetapi di titik DI.21 masuk ke dalam kriteria nyaman hangat. d) yaitu titik di sisi timur yang di dekatnya tidak terdapat bukaan, memiliki suhu efektif DI.05 sebesar $26.42^{\circ} \mathrm{C}$; yang masuk kriteria nyaman hangat namun DI.25 sebesar $25.14^{\circ} \mathrm{C}$ masuk kriteria nyaman optimal menurut mom dan SNI. e) yaitu titik di sisi utara yang di dekatnya terdapat bukaan, suhu efektif DI.28 sebesar $23.71^{\circ} \mathrm{C}$. suhu efektif yang rendah ini dikarenakan posisi yang dekat dengan bukaan titik ini mempunyai suhu yang masuk kriteria nyaman optimal menurut mom dan SNI.

Jika data tersebut dibandingkan dengan standard kenyamanan menurut mom yang memiliki batas kenyamanan antara $20.5^{\circ} \mathrm{C}$ $27.1^{\circ} \mathrm{C}$ maka keseluruhan titik yang berada di dekat bukaan telah memenuhi standard kenyamanan menurut mom dan SNI karena terletak diantara $20.5^{\circ} \mathrm{C}-27.1^{\circ} \mathrm{C}$. Titik yang di dekatnya tidak terdapat bukaan memiliki suhu efektif yang lebih tinggi daripada titik yang didekatnya terdapat bukaan, bahkan terdapat satu titik di sisi barat dan timur yang disisinya tidak terdapat bukaan yang memiliki suhu 
efektif melebihi standard kenyamanan menurut mom dan SNI.

\subsubsection{Suhu Efektif Pukul 18.30 WIB}

Dibawah ini merupakan data suhu efektif yang didapat dari pengukuran lapangan pada pukul 18.30 WIB.

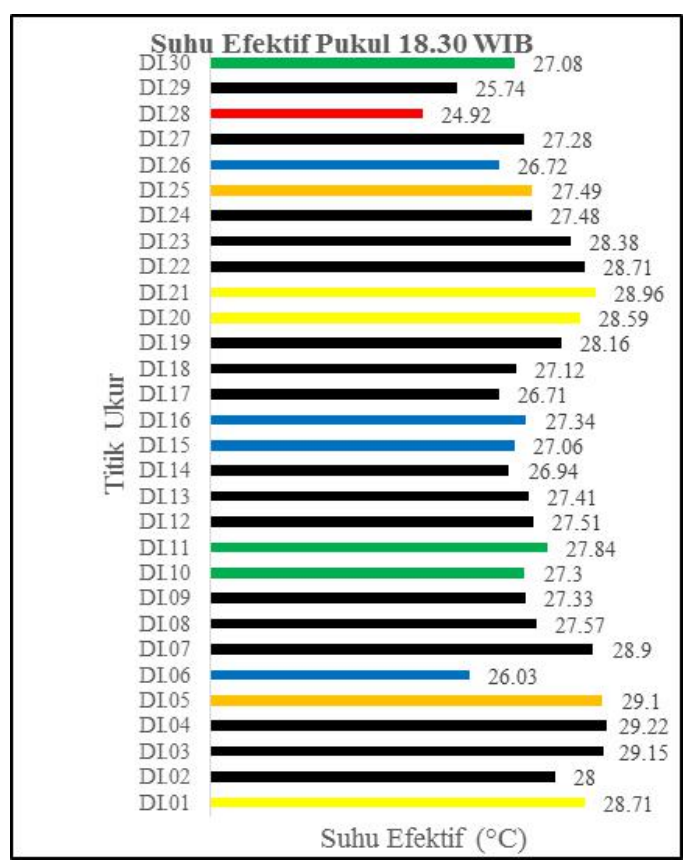

Gambar 18. Diagram Suhu Efektif per Titik Ukur Pukul 18.30 WIB Kondisi Ada Ibadah

Diagram batang terbagi menjadi 2 garis besar yaitu diagram batang "berwarna seklain hitam" merupakan titik ukur di yang berada berdekatan dengan dinding yang dimana titik inilah yang akan dianalisa terkait ada tidak bukaan di sisinya, sedangkan diagram batang yang berwarna hitam adalah titik ukur yang berada jauh dari dinding dan tidak masuk dalam analisa karena titik tersebut lebih dekat dengan kipas angin daripada bukaan. Terkait 2 hal tersebut kaitannya dengan rata rata kondisi suhu di dalam bangunan secara keseluruhan (baik berada di dekat dinding maupun tidak telah dibahas pada sub bab nomor 3.1.4 tentang Suhu Efektif. Sedangkan keterangan untuk warna tersebut dibahas dalam subab 2.3 tentang Titik Ukur.

Analisa terkait diagram batang yang berwarna selain hitam (berada di dekat dinding kaitannya dengan ada tidaknya bukaan) adalah sebagai berikut : a) sisi timur yang dekat bukaan memiliki suhu yaitu titik DI.06 sebesar $26.03^{\circ} \mathrm{C}{ }^{\circ} \mathrm{C}$; titik DI.15 sebesar $27.06^{\circ} \mathrm{C}$; titik DI.16 sebesar $27.34^{\circ} \mathrm{C}$ dan DI. $26^{\circ} \mathrm{C}$ dengan suhu efektif $26.76^{\circ} \mathrm{C}$. b) sisi barat yang dekat dengan bukaan memiliki suhu efektif yaitu titik DI.10 sebesar $27.03^{\circ} \mathrm{C}$; DI.11 sebesar $27.84^{\circ} \mathrm{C}$; DI.30 sebesar $27.08^{\circ} \mathrm{C}$. c) sisi timur yang di sisinya tidak terdapat bukaan memiliki suhu efektif yaitu DI. 01 sebesar $28.71{ }^{\circ} \mathrm{C} \quad$; titik D.20 sebesar $28.59^{\circ} \mathrm{C}$; titik DI. 21 sebesar $28.96^{\circ} \mathrm{C}$. d) sisi barat yang di sisinya tidak terdapat bukaan memiliki suhu efektif yaitu titik DI.5 sebesar $29.10^{\circ} \mathrm{C}$; DI.25 sebesar $27.49^{\circ} \mathrm{C}$. e) sisi utara yang dekat bukaan mempunyai suhu efektif sebesar DI.28 sebesar $24.92^{\circ} \mathrm{C}$.

Di poin a) yaitu titik di sisi timur yang di dekatnya terdapat bukaan memiliki suhu efektif titik DI.06 sebesar $26.03^{\circ} \mathrm{C}$; titik DI.15 sebesar $27.06^{\circ} \mathrm{C}$; titik DI.16 sebesar $27.34^{\circ} \mathrm{C}$ dan DI.26 dengan suhu efektif 26.76 ${ }^{\circ} \mathrm{C}$. Hanya satu titik yaitu titik DI.06 yang memiliki suhu efektif dibawah toleransi dengan kategori nyaman hangat, sedangkan suhu efektif lainnya di tidak masuk kriteria nyaman menurut mom dan SNI karena melebihi $27.1^{\circ} \mathrm{C}$. b) yaitu titik di sisi barat yang di dekatnya terdapat bukaan memiliki suhu efektif titik DI.10 sebesar $27.03^{\circ} \mathrm{C}$; DI.11 sebesar $27.84^{\circ} \mathrm{C}$; DI.30 sebesar $27.08^{\circ} \mathrm{C}$, dua titik yaitu D.10 dan DI.30 masuk kedalam kriteria nyaman hangat sedangkan titik D.11 tidak masuk dalam standard nyaman karena lebih dari $27.1^{\circ} \mathrm{C}$. c) yaitu titik di sisi timur yang di dekatnya tidak terdapat bukaan memiliki suhu efektif DI. 01 sebesar $28.71{ }^{\circ} \mathrm{C}$; titik DI.20 sebesar 28.59 ${ }^{\circ} \mathrm{C}$; titik DI. $21^{\circ} \mathrm{C}$ sebesar $28.96^{\circ} \mathrm{C}$ suhu efektif tidak masuk ke dalam kriteria nyaman karena melebihi $27.1^{\circ} \mathrm{C}$. d) yaitu titik di sisi timur yang di dekatnya tidak terdapat bukaan memiliki suhu efektif DI.05 sebesar $29.10^{\circ} \mathrm{C}$; DI.25 sebesar 27.49 suhu efektif tidak masuk ke dalam kriteria nyaman karena meleibhi $27.1^{\circ} \mathrm{C}$ e) yaitu titik di sisi utara yang di dekatnya terdapat bukaan memiliki suhu efektif DI.28 sebesar $24.92^{\circ} \mathrm{C}$. suhu efektif yang rendah ini dikarenakan posisi yang dekat dengan bukaan titik ini mempunyai suhu yang masuk kriteria nyaman optimal menurut mom dan SNI.

Jika data tersebut dianalisa dengan standard kenyamanan menurut mom yang memiliki batas kenyamanan antara $20.5^{\circ} \mathrm{C}-27.1^{\circ} \mathrm{C}$ 
maka titik yang berada di dekat bukaan memiliki suhu efektif yang lebih rendah dibandingkan titik yang di dekatnya tidak terdapat bukaan. Dengan penjelasan sebagai berikut : (1). Titik DI.06 memiliki suhu efektif yang paling rendah yaitu $26.03^{\circ} \mathrm{C}$ diantara titik lain yang berada di dekat bukaan sisi timur, yang kedua adalah titik DI.26 dengan suhu efektif $26.76^{\circ} \mathrm{C}$, kedua titik tersebut masuk kedalam kriteria nyaman optimal menurut mom dan SNI. Jika dilihat di lapangan fenomena tersebut mungkin terjadi karena 2 titik tersebut memiliki sisi selasar di sisi kiri yang tidak tertutup banner sehingga udara yang masuk cukup banyak. Dibandingkan titik DI.15 sebesar $27.06^{\circ} \mathrm{C}$ (nyaman hangat) ; titik DI.16 sebesar $27.34^{\circ} \mathrm{C}$ (melebihi batas optimal) yang di sisi selasarnya tertutup banner. (2).Titik D.10 sebesar $27.03^{\circ} \mathrm{C}$ (nyaman hangat) dan D.11 sebesar $27.84^{\circ} \mathrm{C}$ (melebihi batas nyaman) memiliki suhu efektif yang lebih tinggi daripada titik DI.30 sebesar $27.08^{\circ} \mathrm{C}$ (hangat nyaman), hal ini mungkin terjadi karena titik DI.10 dan DI.12 berada di kerumunan umat, sedangkan di titik DI.30 memiliki suhu efektif lebih rendah karena berada di sisi belakang dengan sedkit jemaat. (3).Titik DI 28 memiliki suhu efektif paling rendah yaitu $24.92^{\circ} \mathrm{C}$ hal ini dimungkinkan karena titik tersebut lokasinya dekat dengan dengan pintu utama yang memilliki dimensi cukup besar. Titik ini masuk ke katagori nyaman optimal. (4).Titik yang tidak terdapat bukaan memiliki suhu yang lebih tinggi dibandingkan titik yang di dekatnya terdapat bukaan. Dengan rincian

A. titik DI.01 yang berada di sisi barat $28.71^{\circ} \mathrm{C}$ (melebihi batas nyaman). B.titik DI.05 yang berada di sisi timur $29.1^{\circ} \mathrm{C}$ (melebihi batas nyaman). C. titik DI.20 yang berada di sisi barat $28.59^{\circ} \mathrm{C}$ (melebihi batas nyaman). D.titik DI.21 yang berada di sisi barat $28.96^{\circ} \mathrm{C}$ (melebihi batas nyaman). E. titik DI.25 yang berada di sisi timur $27.49^{\circ} \mathrm{C}$ (melebihi batas nyaman).

Pada bangunan gereja ini di sisi timur terdapat selasar yang diberi kisi kisi di sisinya dan dipasang banner dibagian tengah diatas batas kepala sampai di sisi paling atas sebagai pennghalang matahari akan tetapi di sisi utara dan selatan masih terbuka tidak ada halangan apapun.

\subsection{Perbandingan Luas Bukaan Dan Luas Ruang}

\subsubsection{Bukaan Pada Ruang Ibadah.}

Ruang ibadah gereja ini memiliki luas 807.53 $\mathrm{m}^{2}$ dengan beberapa bukaan di dinding baik dibawah berupa pintu maupun diatas berupa bouvenlight.

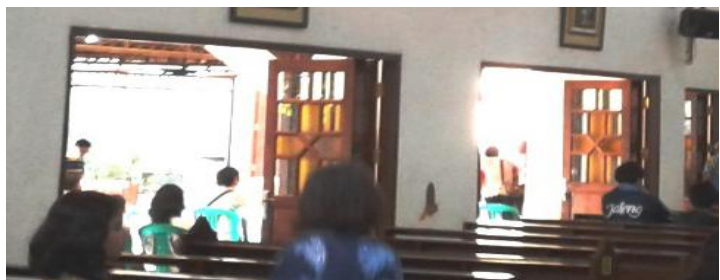

Gambar 19. Bukaan berupa pintu di Gereja Santo Petrus Sambiroto

Gambar diatas menunjukan bukaan yang ada di dinding bagian bawah berupa pintu.

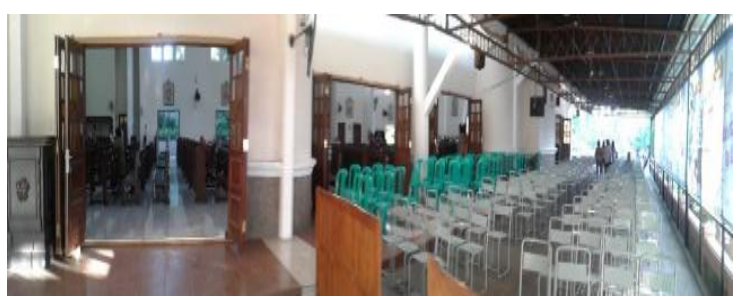

Gambar 20. Bukaan berupa pintu di Gereja Santo Petrus Sambiroto jika dilihat dari arah selasar

Gambar diatas menunjukan bukaan yang ada di dinding bagian bawah berupa pintu jika dilihat dari arah selasar

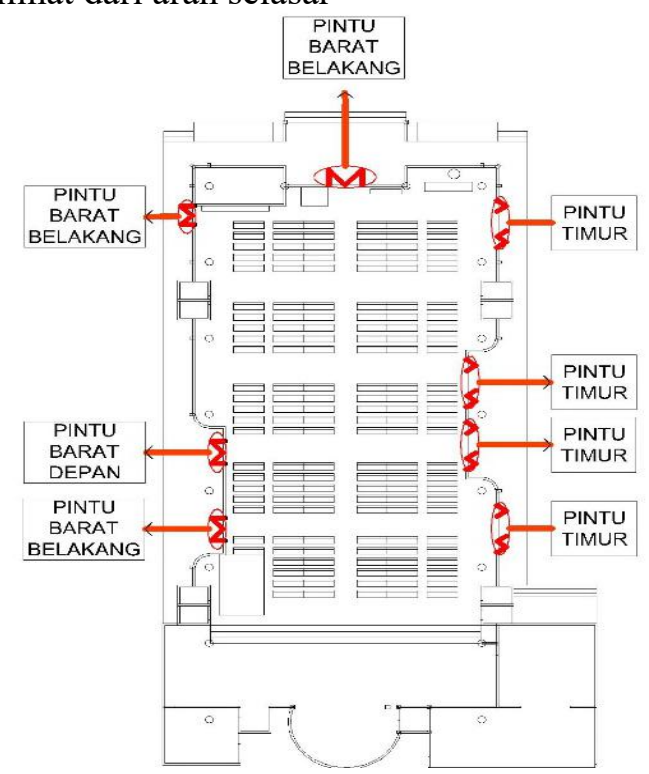

Gambar 21. Titik bukaan berupa pintu di Gereja Santo Petrus Sambiroto

Gambar 21 merupakan gambar bukaan berupa pintu yang ada di dinding gereja. 


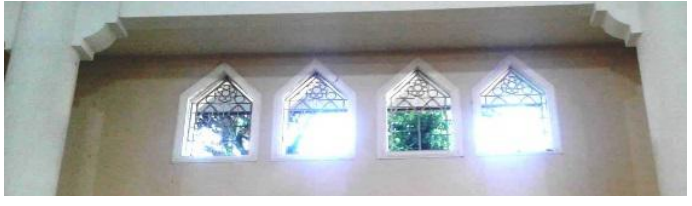

Gambar 22. Bukaan berupa bouvenlight di Gereja Santo Petrus Sambiroto

Gambar 22 menunjukkan bukaan yang ada di dinding bagian atas berupa bouvenlight yang dilengkapi teralis namun tidak diberi kaca.

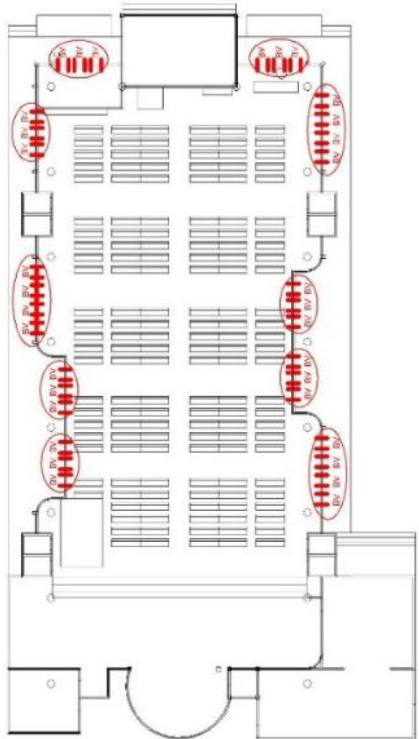

Gambar 23. Titik bukaan btas Gereja Santo Petrus Sambiroto

Gambar diatas merupakan gambar bukaan berupa bouvenlight yang ada di dinding bagian atas gereja.

\section{A. Luas Bukaan Ruang Ibadah}

Berdasarkan gambar-gambar dan penjelasan diatas maka berikut adalah perhitungan luas bukaan pada ruang ibadah gereja :

Tabel 5. Ukuran Bukaan pada Ruang Ibadah Gereja Santo Petrus Sambiroto

\begin{tabular}{|c|c|c|c|c|c|c|}
\hline \multicolumn{7}{|c|}{ Luas Bukaan Ruang Ibadah } \\
\hline $\begin{array}{c}\text { Posisi } \\
\text { Bukaan }\end{array}$ & Tipe & $\begin{array}{l}\text { Ting- } \\
\text { gi } \\
\text { (m) }\end{array}$ & $\begin{array}{l}\text { Pan- } \\
\text { jang } \\
\text { (m) }\end{array}$ & $\begin{array}{l}\text { Luas } \\
\left(\mathrm{m}^{2}\right)\end{array}$ & $\begin{array}{l}\text { Jum- } \\
\text { lah }\end{array}$ & $\begin{array}{l}\text { Total } \\
\left(\mathbf{m}^{2}\right)\end{array}$ \\
\hline $\begin{array}{l}\text { Bawah } \\
\text { Timur }\end{array}$ & Pintu & 2.1 & 3.7 & 7.77 & 4 & 31.08 \\
\hline $\begin{array}{c}\text { Bawah } \\
\text { Utara }\end{array}$ & Pintu & & & $\begin{array}{c}6.33 \\
34 \\
\end{array}$ & 1 & $\begin{array}{c}6.333 \\
4\end{array}$ \\
\hline \multirow{2}{*}{$\begin{array}{c}\text { Bawah } \\
\text { Barat }\end{array}$} & Pintu & 2.1 & 1.54 & $\begin{array}{c}3.23 \\
4\end{array}$ & 2 & 6.468 \\
\hline & Pintu & 2.1 & 1.83 & $\begin{array}{c}3.38 \\
4\end{array}$ & 1 & 3.384 \\
\hline $\begin{array}{l}\text { Atas } \\
\text { Timur }\end{array}$ & $\begin{array}{c}\text { Bouven } \\
\text { light }\end{array}$ & & & $\begin{array}{c}0.81 \\
75\end{array}$ & 14 & $\begin{array}{c}11.44 \\
5\end{array}$ \\
\hline $\begin{array}{l}\text { Atas } \\
\text { Utara }\end{array}$ & $\begin{array}{c}\text { Bouven } \\
\text { light }\end{array}$ & & & $\begin{array}{c}0.81 \\
75\end{array}$ & 6 & 4.905 \\
\hline Atas & Bouven & & & 0.81 & 13 & 10.62 \\
\hline
\end{tabular}

\begin{tabular}{|c|c|c|c|c|c|c|}
\hline \multicolumn{7}{|c|}{ Luas Bukaan Ruang Ibadah } \\
\hline $\begin{array}{c}\text { Posisi } \\
\text { Bukaan }\end{array}$ & Tipe & $\begin{array}{c}\text { Ting- } \\
\text { gi } \\
\text { (m) }\end{array}$ & $\begin{array}{l}\text { Pan- } \\
\text { jang } \\
\text { (m) }\end{array}$ & $\begin{array}{l}\text { Luas } \\
\left(\mathbf{m}^{2}\right)\end{array}$ & $\begin{array}{c}\text { Jum- } \\
\text { lah }\end{array}$ & $\begin{array}{l}\text { Total } \\
\left(\mathbf{m}^{2}\right)\end{array}$ \\
\hline Barat & light & & & 75 & & 75 \\
\hline \multicolumn{6}{|c|}{ Total $\left(\mathrm{m}^{2}\right)$} & $\begin{array}{c}74.24 \\
29\end{array}$ \\
\hline
\end{tabular}

Persentase bukaan pada ruang ibadah

$=$ Luas Bukaan/ Luas Lantai x 100\%

$=74.2429 / 807.52 \times 100 \%$

$=9.2 \%$.

Persentase bukaan sebanyak $9.2 \%$ telah memenuhi syarat menurut (SNI 03-6572-2001,) Tata Cara Perancangan Sistem Ventilasi dan Pengkondisian Udara Pada Bangunan Gedung yaitu 5\% dari luas lantai.

\subsubsection{Bukaan Pada Selasar}

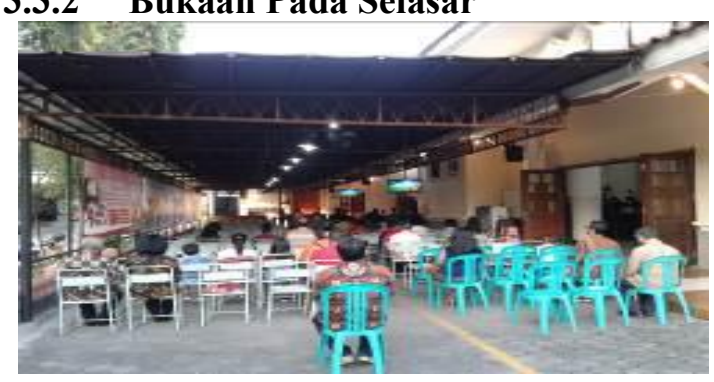

Gambar 24. Kondisi pada Selasar Gereja Santo Petrus Sambiroto

Gambar 24 merupakan kondisi selasar, sisi kanan (barat) berbatasan dengan ruang ibadah gereja, sedangkan sisi kiri (timur) berbatasan dengan halaman gereja.

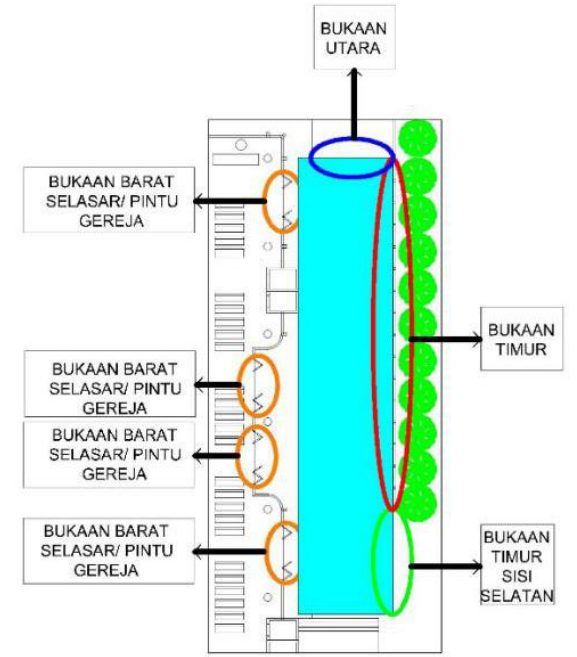

Gambar 25. Bukaan pada Selasar Gereja Santo Petrus Sambiroto

Gambar 25 merupakan gambar selasar timur dengan luas Ruangan $202.96 \mathrm{~m} 2$, selasar tersebut (warna bitu) digunakan untuk kegiatan apabila area dalam gereja tidak mencukupi lagi, di sisi selasar ini sebenarnya bersifat terbuka, 
bagian barat berbatasan dengan bangunan gereja, bagian selatan berbatasan dengan ruang persiapan petugas ibadah, bagian utara berbatasan dengan area luar, sedangkan di area timur berbatasan dengann sisi luar gereja pula, akan tetapi sisi ini dipasang banner gereja yang digunakan untuk melindungi jemaat dari panas matahari pagi akan tetapi justru mungkin dapat menghalangi udara masuk.

\section{Bukaan Selasar Sisi Timur}

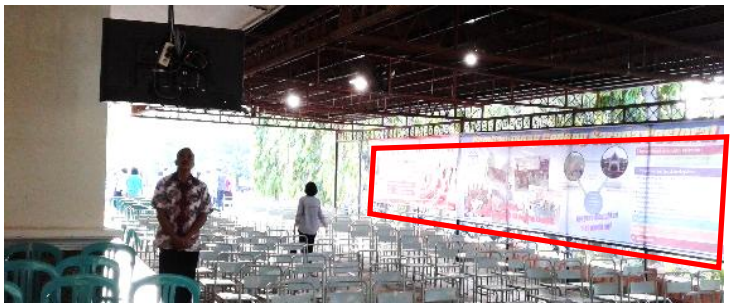

Gambar 26. Kondisi Bukaan dan Banner pada Sisi Timur Selasar Gereja Santo Petrus Sambiroto

Gambar 26 merupakan gambar kondisi selasar timur gereja dengan adanya banner dan bukaan.

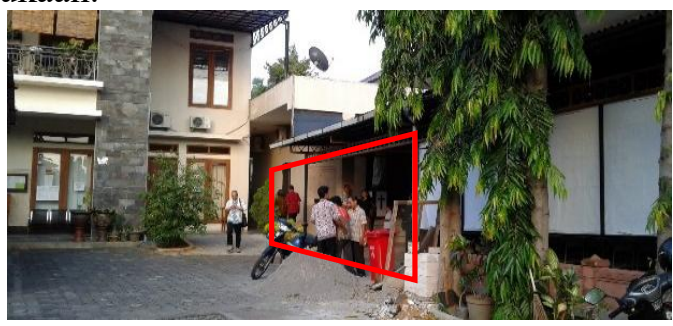

Gambar 27. Bukaan Timur Sisi Selatan pada Selasar Gereja Santo Petrus Sambiroto

Gambar 27 merupakan posisi bukan pada selasar timur gereja, bukaan ini berada di sisi selatan selasar dan menghadap ketimur. Untuk penjelasan dari kedua gambar diatas adalah divisualkan pada Gambar 28.

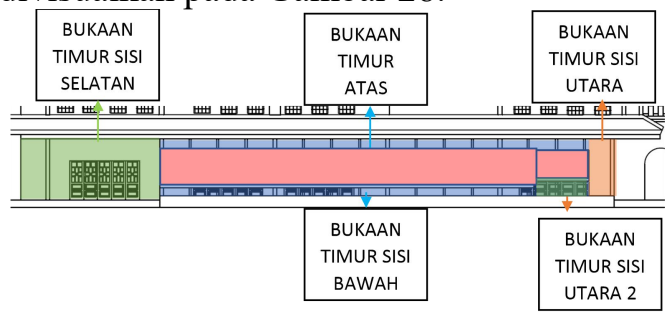

Gambar 28. Bukaan pada Selasar Gereja Santo Petrus Sambiroto

Gambar 28 menunjukkan bukaan di area selasar jika dilihat dari sisi timur di luar gereja, yang dimana sisi ini tertutup oleh wind obstacle berupa banner terdapat bukaan di sisi selatan yang ditunjukan dengan warna hijau di sisi kiri memiliki luas $38.5 \mathrm{~m}^{2}$, bukaan di sisi atas yang ditunjukan dengan warna biru sisi atas memiliki luas $12.762255 \mathrm{~m}^{2}$, bukaan di sisi bawah yang ditunjukan dengan warna biru sisi bawah memiliki luas $9.541845 \mathrm{~m}^{2}$, bukaan di selasar sisi utara yang ditunjukan dengan warna jingga meiliki luas $1.35 \mathrm{~m}^{2}$, dan bukaan timur sisi utara 2 yang ditunjukan dengan warna hijau di sisi kanan yang mmiliki luas 1.2 $\mathrm{m}^{2}$. Wind obstacle berupa banner ditunjukkan dengan warna merah muda.

\section{Bukaan Sisi Utara Selasar}

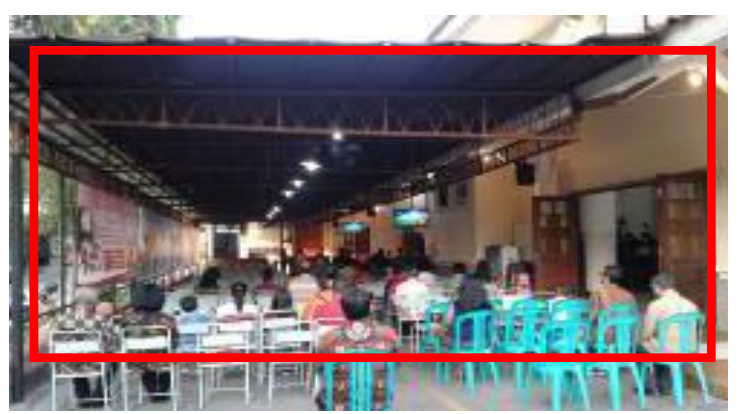

Gambar 29. Kondisi pada Selasar Gereja Santo Petrus Sambiroto

Gambar 29 merupakan gambar yang menunjukkan kondisi eksisting bukaan pada sisi utara selasar gereja, bukaan ini berbatasan dengan sisi luar gereja yang menghadap ke selatan. Sisi yang tidak tertutupi banner ini menjadi lubang untuk masuknya udara dari luar bangunan ke dalam selasar dan ke dalam gereja, selasar ini dipakai jemaat untuk ibadah apabila ruang dalam gereja sudah tidak cukup untuk menampung jumlah jemaat. Untuk lebih jelasnya dapat dilihat pada gambar dibawah.

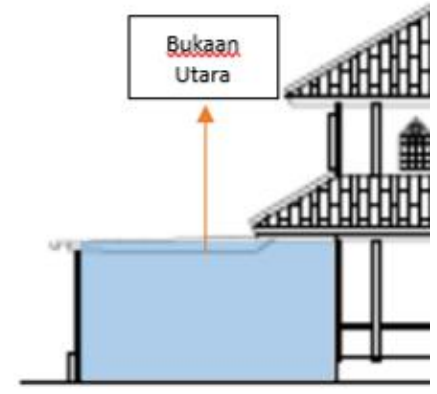

Gambar 30. Bukaan pada Sisi Utara Selasar Gereja Santo Petrus Sambiroto

Gambar 30 merupakan gambar yang menunjukan bukaan pada sisi utara selasar yang dimana sisi ini tidak terdapat wind obstacle berupa banner. Hal tersebut menjadikan bukaan pada sisi ini 
memungkinkan udara dari luar untuk bisa masuk ke area selasar dan selanjutnya masuk ke area gereja. Bukaan sisi utara ini memiliki luas $23.8 \mathrm{~m}^{2}$.

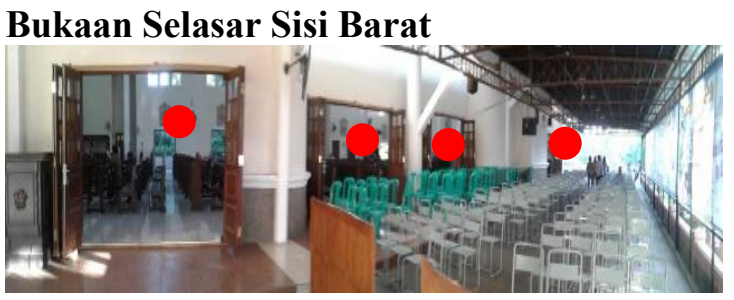

Gambar 31. Bukaan pada Sisi Barat Selasar Gereja Santo Petrus Sambiroto

Gambar 31 menunjukkan bukaan di selasar di sisi barat dimana bukaan ini merupakan pintu masuk ke dalam gereja. Sisi ini mempunyai 4 bukaan dengan ukuran yang sama dengan letak sebagai berikut : 1 di sisi utara, 2 di tengah dan 1 di sisi selatan, untuk lebih jelasnya dapat dilihat pada gambar 14 sisi kiri. Bukaan disisi barat selasar ini memiliki luas $31.08 \mathrm{~m}^{2}$.

\section{A. Perhitungan Luas Bukaan pada Selasar Gereja}

Berdasarkan gambar-gambar dan penjelasan diatas maka berikut adalah perhitungan luas bukaan pada selasar timur gereja disajikan tabel 6 .

Tabel 6. Ukuran Bukaan pada Selasar Gereja Santo Petrus Sambiroto

\begin{tabular}{|c|c|c|c|}
\hline $\begin{array}{c}\text { Posisi } \\
\text { Bukaan }\end{array}$ & $\begin{array}{c}\text { Vertikal } \\
(\mathbf{m})\end{array}$ & $\begin{array}{c}\text { Horisontal } \\
\mathbf{( m )}\end{array}$ & Luas $\left.\mathbf{( m}^{\mathbf{2}}\right)$ \\
\hline $\begin{array}{c}\text { Bukaan } \\
\text { Timur } \\
\text { Bawah }\end{array}$ & 0.45 & 21.2041 & 9.541845 \\
\hline $\begin{array}{c}\text { Bukaan } \\
\text { Timur Atas }\end{array}$ & 0.55 & 23.2041 & 12.762255 \\
\hline $\begin{array}{c}\text { Bukaan } \\
\text { Timur Sisi } \\
\text { Utara }\end{array}$ & 1.5 & 0.9 & 1.35 \\
\hline $\begin{array}{c}\text { Bukaan } \\
\text { Timur Sisi } \\
\text { Utara 2 }\end{array}$ & 0.6 & 2 & 1.2 \\
\hline $\begin{array}{c}\text { Bukaan } \\
\text { Timur Sisi } \\
\text { Selatan }\end{array}$ & 3.5 & 11 & 38.5 \\
\hline $\begin{array}{c}\text { Bukaan } \\
\text { Barat }\end{array}$ & 2.1 & 3.7 & $\begin{array}{c}7.77 \times 4 \\
\text { buah }= \\
\end{array}$ \\
\hline $\begin{array}{c}\text { Bukaan } \\
\text { Utara }\end{array}$ & 3.5 & 6.8 & 23.8 \\
\hline \multicolumn{2}{|c|}{ Total (m²) } & $\mathbf{1 1 8 . 2 3 4 1}$ \\
\hline
\end{tabular}

Persentase Bukaan pada selasar sisi Timur
$=$ Luas Bukaan/ Luas Lantai x 100\%

$=118.2341 / 202,96 \times 100 \%$

$=58.25 \%$.

Persentase bukaan sebanyak $58.25 \%$ telah memenuhi syarat menurut (SNI 03-6572-2001,) Tata Cara Perancangan Sistem Ventilasi dan Pengkondisian Udara Pada Bangunan Gedung yaitu $5 \%$ dari luas lantai.

\section{KESIMPULAN}

Rata-rata suhu kering pada pukul 06.30 WIB, 08.30 WIB, 18.30 WIB berturut-turut adalah $27.37^{\circ} \mathrm{C}, \quad 28.47^{\circ} \mathrm{C}$, dan $30.41^{\circ} \mathrm{C}$. Rata-rata kelembaban relatif pukul $06.30 \mathrm{WIB}, 08.30$ WIB dan 18.30 WIB berturut-turut adalah $76.83 \%$, 82.93\%, dan $84.66 \%$, menurut (S.V Szokolay, 1980) batas kelembaban relatif yang dianjurkan sebesar $30 \%-65 \%$ dengan toleransi hingga $77 \%$. Hal ini menunjukkan bahwa pukul 06.30 WIB kelembaban relatif telah melampaui standard namun belum melampaui toleransi, sedangkan pukul 08.30 WIB dan 18.30 WIB telah melampaui standard dan melampaui batas toleransi. Rata-rata pergerakan udara pada pukul $06.30 \mathrm{WIB}$, 08.30 WIB dan 18.30 WIB berturut-turut adalah $0.56 \mathrm{~m} / \mathrm{s}, 0.50 \mathrm{~m} / \mathrm{s}$, dan $0.50 \mathrm{~m} / \mathrm{s}$, menurut (S.V Szokolay, 1980) pergerakan udara tersebut sudah memenuhi standard yang dianjurkan yaitu lebih dari $0.2 \mathrm{~m} / \mathrm{s}$. Rata-rata suhu efektif pukul $06.30 \mathrm{WIB}, 08.30 \mathrm{WIB}$ dan 18.30 WIB berturut-turut adalah sebesar $23.45^{\circ} \mathrm{C}, \quad 24.98^{\circ} \mathrm{C}$, dan $27.5^{\circ} \mathrm{C}$, menurut standard mom dalam (Soegijanto, 1998) dan (SNI 03-6572-2001,) tentang Tata Cara Perancangan Sistem Ventilasi dan Pengkondisian Udara Pada Bangunan Gedung, pukul 06.30 WIB dan 08.30 WIB masuk pada kriteria nyaman optimal yaitu $22.8^{\circ} \mathrm{C}-25.8^{\circ} \mathrm{C}$, sedangkan pukul $18.30 \mathrm{WIB}$ telah melampaui standard nyaman yang dianjurkan yaitu $20.5^{\circ} \mathrm{C}-27.1^{\circ} \mathrm{C}$.

Titik yang terletak di dekat bukaan memiliki suhu efektif yang lebih rendah dan pergerakan udara yang lebih tinggi dibandingkan dengan titik yang tidak terletak di dekat bukaan. Hal ini membuktikan bahwa bukaan mempunyai peran terhadap kondisi termal yaitu semakin besar bukaan maka semakin besar pula pergerakan udara yang ada dan semakin kecil suhu efektifnya. 
Adanya wind obstacle berupa banner yang ada di selasar juga berpengaruh dalam mengalirkan udara dari luar ke dalam untuk menciptakan kenyamanan termal di ruang ibadah. Hal ini dibuktikan dengan area yang terhalangi wind obstacle mempunyai suhu efektif yang lebih tinggi dibandingkan dengan area yang tidak terhalangi.

Dimensi bukaan sebesar $9.2 \%$ pada dinding gereja dan $46.76 \%$ pada selasar telah memenuhi standard menurut (SNI 03-65722001,) tentang Tata Cara Perancangan Sistem Ventilasi dan Pengkondisian Udara Pada Bangunan Gedung yaitu lebih dari 5\% dari luas lantai, namun walau luas bukaan yang ada sudah sesuai standard dan telah dibantu kipas angin, pada pukul 18.30 WIB suhu efektif tidak mampu mencapai standard kenyamanan, maka dari itu sebaiknya pihak gereja menerapkan kembali konsep awal desain dengan melepas banner yang ada untuk memaksimalkan aliran udara dari luar menuju ke dalam bangunan sebagai upaya menurunkan suhu efektif dan memperoleh suhu efektif yang sesuai standard kenyamanan. Di sisi lain intensitas penggunaan kipas angin pun dapat dikurangi sebagai upaya penghematan energi.

Jika kedepannya sisi selasar akan dibangun maka sebaiknya pada sisi timur selasar, selatan selasar, dan utara selasar dibuat bukaan yang luas untuk memperbanyak aliran udara yang masuk guna menurunkan suhu efektif agar dapat mencapai kenyamanan termal.

\section{UCAPAN TERIMAKASIH}

Kepada pihak Gereja Santo Petrus Sambiroto Semarang karena telah mengijinkan peneliti untuk melakukan penelitian di Gereja Santo Petrus Sambiroto Semarang.

\section{REFERENSI}

Aflaki, A., Mahyuddin, N., Al-Cheikh Mahmoud, Z., \& Baharum, M. R. (2015). A review on natural ventilation applications through building façade components and ventilation openings in tropical climates. Energy and Buildings, 101, 153-162. https://doi.org/10.1016/j.enbuild.2015.04.033

Amin, M., Danusputra, H., \& Prianto, E. (2004). Pengaruh Bukaan Terhadap Kenyamanan Thermal pada Bangunan Publik di Daerah Tropis. Jurnal Unimus, 1-13.
Badan Standardisasi Nasional. (2001). Tata Cara Perancangan Sistem Ventilasi dan Pengkondisian Udara pada Bangunan Gedung.

Badan Standardisasi Nasional. (2004). Pengukuran Iklim Kerja (panas) dengan Parameter Indeks Suhu Basah dan Bola.

Carera, A., \& Prianto, E. (2016). Karakter Kenyamanan Thermal pada Bangunan Ibadah di Kawasan Kota Lama, Semarang. Prosiding SNST Fakultas Teknik, 1(1), 15-19.

Frick, H., Ardiyanto, A., \& Darmawan, A. (2008). Ilmu Fisika Bangunan (8th ed.). Yogyakarta: Kanisius.

Koenigsberger, O. H., Ingersoll, T. G., Mayhew, A., \& Szokolay, S. V. (1974). Manual of tropical housing and building. Part one. Climatic design. London: Longman.

Prianto, E., Bonneaud, F., Depecker, P., \& Peneau, J.-P. (2000). Tropical-Humid Architecture in Natural Ventilation Efficient Point of View A Reference of Traditional Architecture in Indonesia. International Journal on Architectural Science, 1(2), 80-95.

Razak, H. (2015). Pengaruh Karakteristik Ventilasi dan Lingkungan Terhadap Tingkat Kenyamanan Termal Ruang Kelas SMPN di Jakarta Selatan. AGORA Jurnal Penelitian Dan Karya Ilmiah Arsitektur Usakti Jurnal Penelitian Dan Karya Ilmiah Arsitektur Usakti, 15(2), 1-18. https://doi.org/10.25105/agora.v15i2.2024

Rusmiatmoko, D., Setyowati, E., \& Hardiman, G. (2018). Kontribusi Lubang Angin dan Ventilasi Udara pada Bangunan Sobokartti Semarang dalam Mewujudkan Kenyamanan Termal. MODUL, 18(2), 90-96. https://doi.org/https://doi.org/10.14710/mdl.1 8.2.2018.90-96

S.V Szokolay. (1980). Environmental Sciences Handbook for Architects and Builders. Lancaster [etc.] : Construction Press.

Santoso, E. I. (2012). Kenyamanan Termal Indoor pada Bangunan di Daerah Beriklim Tropis Lembab. Indonesian Green Technology, 1(1), 13-19.

Sekatia, A., Setyowati, E., \& Hardiman, G. (2015). Efektivitas Ventilasi Bawah Terhadap Kenyamanan Dan Pmv (Predicted Mean Vote) Pada Gereja Katedral, Semarang. AGORA Jurnal Penelitian Dan Karya Ilmiah Arsitektur Usakti, 15(2), 39-52. https://doi.org/10.25105/agora.v15i2.2026

Soegijanto. (1998). Bangunan di Indonesia dengan Iklim Tropis Lembab Ditinjau dari Aspek Fisika Bangunan. Jakarta: Departemen Pendidikan dan Kebudayaan. 